\title{
“Do You Love China or Not?": Late-Colonial Textbooks to Learn Mandarin through Malay
}

\author{
Tom Hoogervorst
}

\section{1 \\ Introduction $^{1}$}

On 2 October 1913, roughly two years after the Republic of China was founded, a long letter landed on the desk of the Netherlands Indies governor-general Idenburg. In it, a senior advisor to the colonial government on Chinese affairs, William J. Oudendijk, provided detailed recommendations to improve the education of its Chinese subjects. Government-facilitated opportunities had been disappointingly inadequate, he contended, so that many families opted to send their children to schools oriented to China rather than the Netherlands. This situation was inexcusable if the Chinese were to become full participants of the Dutch Empire. Having studied in Beijing, the seasoned diplomat was furthermore unimpressed with the level of Mandarin taught in the archipelago:

Not only is Mandarin currently in fashion as a working language, but, amidst the large variety of dialects spoken by the resident Chinese, the large difficulty of choosing one dialect is resolved if Mandarin is adopted. Let me immediately add that in most schools a very peculiar language passes for Mandarin, and that a great many teachers simply just speak their own provincial dialect, sometimes with a little touch of Mandarin. ${ }^{2}$

What did this peculiar type of would-be Mandarin look like, or, rather, sound like? What sources are available to reconstruct its early history in

1 Throughout this chapter, I will cite the Chinese data in their original transcription. To identify their contemporary pronunciations, I use Pìnyìn for Mandarin and Péh-ōe-j̄̄ for Hokkien.

$2[\ldots]$ het Mandarijnsch is thans als voertaal niet alleen in de mode, doch bij de groote verscheidenheid der door de hier gevestigde Chineezen gesproken dialecten wordt de groote moeilijkheid der keuze van een dialect doorgehakt zoo men Mandarijnsch neemt. Laat ik hier terstond bijvoegen, dat in de meeste scholen een heel raar taaltje voor Mandarijnsch moet doorgaan, en dat zeer vele onderwijzers maar heel eenvoudig hun eigen provinciaal dialect spreken, soms met een Mandarijnsch tintje er aan (van der Wal 1963: 263). 
Indonesia? What can the story of Netherlands Indies Mandarin tell us about Chinese-Indonesian history more broadly?

Roughly speaking, the history of Mandarin in Indonesia exhibits two distinct periods. The first started at the turn of the twentieth century, when efforts to modernize Chinese education - both in China and among the Chinese-descended communities in Southeast Asia - led to the widespread adoption of Mandarin as the language of instruction at the expense of preexisting varieties such as Hakka, Cantonese, Teochew, and especially the Zhangzhou variety of Hokkien. In the Netherlands Indies - as Indonesia was known under Dutch colonialism - the Chinese Meeting Hall or Tiong Hoa Hwe Koan 中華會館 played a crucial role in the establishment of modern Mandarin-medium schools (Suryadinata 1972; Sai 2016; Kwartanada 2018). Mandarin continued to be taught under the Japanese occupation (1942-45) and in Sukarno-era Indonesia (1945-66). From 1966 to 1998, Chinese education and linguistic expressions were banned as part of the assimilationist regime of Indonesia's second president, Soeharto, leading to a period of cultural disruption and destruction (Heryanto 1998; Sai 2006). The second period of Mandarin education in Indonesia, hence, only started after 1998, when the ban on Chinese education was lifted and numerous Chinese-descended Indonesians began to reconnect with their Chinese identity (Sai 2010; Setijadi 2015).

The present chapter deals with the first period - roughly the first half of the twentieth century - which to my knowledge has not yet received much linguistic attention. It investigates the way Chinese-Indonesians in the latecolonial period learned Mandarin, the specific type of Mandarin they were taught, and the material they used. By comparing several textbooks that relied on Malay/Indonesian as the language of instruction, I will examine, at once, the linguistic characteristics and the contents of the teaching material. Unlike "Malaysian Mandarin" or "Singaporean Mandarin" (Goh 2017), the Indonesian variety of Mandarin was never broadly adopted even amongst the Chinese themselves. Nevertheless, its linguistic features tell a compelling story of Chinese-Indonesian cultural and political contestations during a pivotal part of their history. The academic appeal of Mandarin in late-colonial Indonesia arguably lies in its heterogeneity, having been adopted more than three decades before language planners in China agreed on a unified pronunciation (cf. Sai 2016: 378-79). Some Mandarin teachers in the Indies used orthographic conventions derived from the Dutch language. Intellectually, however, they were relatively free from European structures of education. The contents of their teaching books, especially the example sentences, make it clear that colonialism was incompatible with the aspirations of this generation of pan-Chinese 
chauvinists. As I hope to demonstrate, many of the phrases in Mandarin teaching materials reveal insights into the language practices of their authors and intended readership, but also concrete formulations of their worldview.

But first, the concept "Mandarin" merits some clarification. The original European usage of this word corresponds to the Chinese term guānhuà 官話 'language of officials' as used during the Ming and Qing dynasties. Especially in the Qing Dynasty, guānhuà was a non-standardized prestige variety (koiné) that had emerged from contact between several mutually intelligible dialects. It tolerated a degree of regional variety from běizinn 北音 'northern pronunciations' and nányin 南音 'southern pronunciations', spoken respectively in the Beijing and Nanjing area (Coblin 2007: 23; Simmons 2017: 72). Even with Beijing at the centre of political power, most literati preferred the prestigious southern variety of Nanjing until the early twentieth century (Coblin 2000: 267-68; Simmons 2017: 67; Kuiper 2017: 88 fn. 186). Influenced by Japanese and Western notions of state formation and accompanied by ideas of a Correct Pronunciation (正音 zhèngyinn), the concept of a National Language (國語 guóyǔ) gradually gained ground among Chinese intellectuals around the turn of the twentieth century (Coblin 2007: 43). In its final years, the Qing government proposed a guóyú based on the Beijing variety, enriched with some southern Mandarin features (Simmons 2017: 73). A more mixed interdialectal model known as Blue-Green Mandarin (藍青官話 lánqīng guānhuà) ${ }^{3}$ was promoted by the Roc from 1912, yet this project failed due to the absence of native speakers (Li 2004: 102; Simmons 2017). In the 1920s, support grew for a New National Pronunciation (新國音 xin guóyinn), for which the Nanjing-influenced educated stratum of Beijing Mandarin served as a concrete dialect base. This variety was officially promulgated in 1932 (Li 2004: 103; Coblin 2007: 24; Simmons 2017: 79-82). Concomitant to this development was the popularity of báihuà 白話 - the vernacular idiom, as opposed to Classical or Literary Chinese - as a modern written language accessible to the masses (Weng 2018).

The impact of these developments on the history of Mandarin in Indonesia and elsewhere in Southeast Asia remains poorly studied. Many ChineseIndonesians were more literate in Malay, the archipelago's lingua franca, than in any Sinitic variety. In addition, many could speak and write regional Indonesian languages, such as Javanese and Sundanese. From the early twentieth century, however, the so-called Sino-Malay press regularly called attention to guóyǔ and báihuà - spelled as kuo-yü and pai hwa - and the perceived importance for Indies Chinese to learn them. The term zhèngyìn - in

3 So named because it contained regional and non-standard features and was thus "neither purely blue nor purely green" (Simmons 2017: 63-64, fn. 1). 
the archipelago typically pronounced as tjeng im (literary Hokkien: chèngim) or tjia im (colloquial Hokkien: chiàn-im) - was used synonymously with Mandarin. Yet unlike mainland China, Indonesia lacked native-speaking reference points for this language. Job Moerman, an elementary teacher at Chinese schools, observed in 1929 that Mandarin was only used for reading (Moerman 1929: 43). The Chinese-Indonesian journalist Nio Joe Lan 梁友蘭, writing in 1932, noticed that students who had learned Mandarin at school rarely used it at home, where other Sinitic varieties and/or Malay prevailed (Nio 1932: 1092). This situation is reminiscent to what has been observed among Singaporean Chinese in the 1990s - "Mandarin no longer has any relationship to their lived reality. At most it simply triggers a sentimental connection ... the study of Mandarin is actually the study of a foreign language" (Wang 1993 quoted by Ng 2013: 84) - although for many people "no longer has" could be replaced by "never had". Only a very small number of recent migrants from Hunan and northern China reportedly spoke Mandarin natively, and many of them predictably worked as teachers at private Chinese schools (Moerman 1929: 27). Nevertheless, growing numbers of Chinese-Indonesians sought to further their education in China from 1906 (Suryadinata 1972: 62-63; Sai 2006: 151; Hoogervorst 2021: 45), where they must have improved their Mandarin proficiency. On a local level, too, opportunities abounded to study the language (Fig. 7.1). The specific type of Mandarin they learned, hence, merits academic attention.

\section{$2 \quad$ Learning Chinese in Indonesia}

Mandarin is Indonesia's only Sinitic language for which courses and textbooks were publicly advertised. In late-colonial times, they were often promoted in the verbiage of pan-Chinese solidarity, typically in Malay (Hoogervorst 2021: 42-50). If one truly supported Chinese nationalism and wished to transcend provincial loyalties, so the argument went, the adoption of a shared national language was the only viable option. Such sentiments could of course easily be exploited for commercial gain. The following advertisement, for instance, inexorably connects a person's love for the Chinese nation to their willingness to purchase a long list of textbooks:

Do you ...?

Do you like the Chinese nation?

Do you want to know about the Chinese civilization?

Do you want to become a friend of the Chinese nation? 


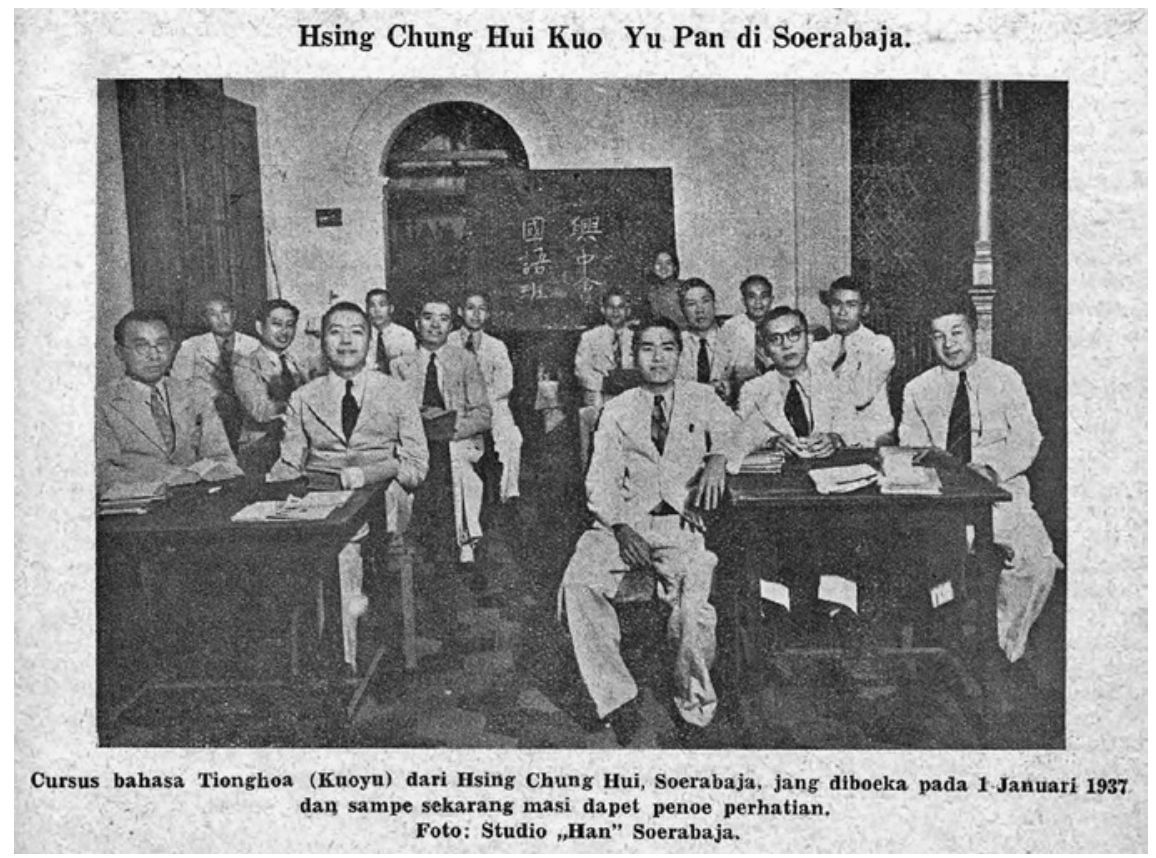

FIGURE 7.1 Photo of a Mandarin course in Surabaya FROM SIN PO WEKELIJKSCHE EDITIE 841 (1939), 5. THE COURSE WAS PROVIDED BY THE REVIVE CHINA SOCIETY OR HSING CHUNG HUI 興中會. NO KNOWN COPYRIGHT HOLDERS

Do you plan to go to China?

Do you understand the Mandarin Chinese language?

Do you enjoy learning the Chinese script?

Do you want to learn the Mandarin Chinese language?

Do you want to interact with the civilized Chinese nation? ${ }^{4}$

Other institutions provided opportunities to learn Mandarin for free. Another advertisement, published in 1924 in the Sino-Malay newspaper Tjin Po 貞報, invokes the perennial bugbear of cultural attrition. As we can read below, the Sino-Malay newspaper Keng Po 競報 offered a free course according to the system created by a certain Tjiam Dji Ko, of whom I have not been able to find any further information:

4 Apatah ...? | Apatah Toean soeka sama bangsa Tionghoa? | Apatah Toean ingin kenal kasopanan Tionghoa?|Apatah Toean maoe djadi sobatnja bangsa Tionghoa?|Apatah Toean aken pergi ka Tiongkok? | Apatah Toean mengarti bahasa Tionghoa Tjeng-Im? | Apatah Toean soeka berladjar hoeroef Tionghoa? | Apatah Toean maoe berladjar bahasa Tionghoa Tjeng-Im? | Apatah Toean ingin bergaoel dengan bangsa T.H. jang sopan? (Tip 1923). 
Learn the Chinese script for free. Seeing as the Chinese schools have failed to become places to prevent the loss of the Chinese language and script among the Indies-born Chinese, starting from 8 April, Keng Po in Batavia will teach five Chinese characters in the Mandarin dialect in each issue, totalling 1000 characters according to Tjiam Dji Ko's system. [...] Support the goal to make Chinese the language of social interaction in the Indies. ${ }^{5}$

The best-rated Chinese schools in the Netherlands Indies managed to offer their entire curriculum in Mandarin, without relying on other languages (Sai 2016: 384). Exclusively Chinese teaching materials were not romanized, although some had phonetic markings known as Zhùyinn Fúhào 注音符號. For more detail on the phonology of Indonesia's early Mandarin, therefore, we must direct our attention to commercially published phrasebooks and dictionaries with explanations in Malay, which the majority of learners would have required. Below, I will briefly highlight the background and contents of this chapter's primary sources.

The first commercially available book known to me from which Indies-born Chinese could hone their Mandarin skills was a 140-page wordlist of Malay, Dutch, Japanese, Mandarin, Hokkien, Hakka, and Cantonese titled East Asia, first published in 1910 by John F. Knoetsen. ${ }^{6}$ Not much is known about the book's compiler, who must have been born around 1873 and worked as a telegraphist and non-military clerk (burgerschrijver) in Palembang, a city in Sumatra. Some of the photographs Knoetsen took of Palembang life at the beginning of the twentieth century are kept at the Leiden University Library. ${ }^{7}$ Netherlands Indies newspapers report that he took a one-year furlough to China in October 1905, where he must have nurtured his Mandarin proficiency. In 1906, the self-taught polyglot briefly taught English at the Tiong Hoa Hwe Koan school in Batavia (Nio 1940: 93-94), which made him a contemporary at that institute of the famous Singaporean educational reformist Lim Boon Keng 林文慶. Next to East Asia, Knoetsen published an English-Malay-Javanese-Sundanese phrasebook (1911), a manual to read and

5 Bladjar hoeroef Tionghoa dengen prodeo. Meliat Haktong telah loepoet mendjadi tempat aken tjega terhilangnja hoeroef dan bahasa Tionghoa antara pranakan-pranakan di Hindia, maka moelaï dari tanggal 8 april KENG PO di Batavia setiap terbitnja ada mengadjar lima hoeroef Tionghoa dalem dialect Tjeng Im sampe 1000 hoeroef systeem Tjiam Dji Ko. [...] Toendjanglah ini maksoed boeat bikin pergaoelan di ini Hindia mendjadi Tionghoa.

6 I have not been able to find the first edition. Copies of the third edition, published in 1912, can be found at the universities of Leiden and Cornell.

7 KITLV 4784, KITLV 1807O7, KITLV 181505. 
write Chinese characters (1931), ${ }^{8}$ a Dutch-Japanese-Malay-English phrasebook for tourists (1934), and a book containing templates for legal correspondence (1935). These were all published by the Chinese-owned printing house Tjiong Koen Bie 鍾昆美 in Batavia, later known under the name De "Pertoendjoengan". Another source of income for Knoetsen, both before and after his retirement in 1919, was the writing of endorsements for pharmaceutical companies; his name can be found in various advertisement for pills against rheumatic pains, haemorrhoids, and other ailments. No amount of medicine could save him, however, when he got hit by a car in 1938 and died at the age of 65 , as several Netherlands Indies newspapers reported.

Unlike the other books discussed in this chapter, East Asia contains only words and no example sentences. Its publication by Tjiong Koen Bie and the laudatory forewords of Chinese dignitaries - the Qing representative Ong Hong Siang 王鳳翔 and the Chinese newspaper editor Pe Pin Chuw 白萍洲 - suggest that Knoetsen was well-established in Chinese circles. As becomes clear from the introduction of the book's second edition (1912), his targeted readership consisted of Chinese and Europeans alike:

Since I have started to publish my little "Handbook", I have noticed that not only local-born Chinese, but also various Europeans are aficionados of those "Handbooks", even though they are chiefly written in Malay; and I have also realized that it is very useful for Dutch traders, travellers, missionaries, and police servants in the Netherlands Indies to learn to speak Japanese or one of the Chinese languages.

That is why I have decided to completely revise the second edition, in such a way that a full-blooded Dutchman, who does not know a single word of Malay, would be able to find with great ease a Dutch word translated into Japanese or Chinese. ${ }^{9}$

8 I have not been able to find any copies of this publication.

9 Sedert dat ik begonnen ben met myn "Handboekje" uit te geven, heb ik bemerkt dat niet alleen hiergeborene Chineezen maar ook verscheidene Europeanen liefhebbers zyn van die "Handboekjes", niettegenstaande de hoofdtaal daarvan Maleisch is; en ook heb ik ingezien, dat het leeren spreken van Japansch of een der Chineesche talen daarin aanwezig zeer nuttig is voor Hollandsche handelaren, reizigers, zendelingen en politie-ambtenaren in Ned: Indië. | Daarom heb ik besloten de tweede uitgave geheel te wyzigen, en wel zoodanig, dat een volbloed Nederlander, die nog geen enkel Maleisch woord kent, zeer gemakkelyk een Hollandsch woord in het Japansch of Chinees vertaald, zou kunnen vinden. (Knoetsen 1912: ii). 
Also in 1912, a Chinese-English-Malay phrasebook titled The Chinese, English and Malay Classified Conversations was published by Chun Lim \&Co 振林公司 in Batavia. ${ }^{10} \mathrm{I}$ have not been able to find anything about its compilers: K.S. Chu or K.S. Tjoe, S.L. Kim, and B.S. Lim. I suspect the latter was Lim Bok Sioe 林木秀, a close associate of the Tiong Hoa Hwe Koan and the Sino-Malay newspaper $\operatorname{Sin} P o$ 新報. Judging from some of the example sentences, not all editors were fluent in Malay. Most of the chapters prepare the Indies-born reader for a stay in China. They include conversations about carriages, railroad transportation, ships, custom houses, hotels, and leisure options one was anticipated to enjoy in the "homeland". The book's English introduction made the point that knowledge of Mandarin was essential for the ethnic Chinese residing in Southeast Asia - at the expense of their pre-existing linguistic repertoires - to become part of the Chinese nation:

In China, the Mandarin language is chiefly used either in the Northern or Southern China; but most of the Chinese, in the Southern island or in the Malay Archipelago, frequently use the Malay language, or some other languages such as Cantonese or Hokianese [sic!], and by continuing these languages so frequently and being so accustomed to them, that they have entirely forgotten one principal language - the language chiefly spoken amongst the Chinese, inhabitants of China and that is the Mandarin language

CHU ET AL. 1912: i

A third important publication appeared in 1920 under the title Combining Chinese and Malay or Hoa Woe Ho Pie 華巫合璧.1 ${ }^{11}$ This phrasebook was written by the Meixian-born Chun Foo Chun 陳撫辰, who had settled in Batavia in 1906 to engage in educational work among the Indies Chinese. From 1911, he also promoted several Chinese commodities in the Netherlands Indies (CWR 1936: 27). Of the 7 language manuals and 10 Malay novels Chun Foo Chun reportedly authored (ibid.), the majority have gone lost. His 1930 New Malay-Chinese Dictionary or Sin Woe Hoa Tze Tian 新巫華字典, of which a copy is kept at the National Library of Singapore, is worth mentioning. In addition, Chun Foo Chun wrote short manuals on Chinese medicine (1915) and, as he phrased it, on important matters women should know (1917). Politically, Chun was a formal

10 Malay: Boekoe Omong-Omongan Njang Teratoer Darie Bahasa Tjina, Inggris dan Malayoe. The only copy of this publication known to me is kept at the Museum of ChineseIndonesian Literature (Museum Pustaka Peranakan Tionghoa) in Tangerang, Indonesia.

This publication has recently been digitized by Cornell University. 
representative of the Chinese Republican government. Commercially, he was associated with J. Lowe Medicine Co. 羅威藥房 in Shanghai and - together with Lim Bok Sioe - with the aforementioned publishing house Chun Lim \&Co. Due to Chun's close links with Chinese journalists and educationists in the Indies, advertisements for his Hoa Woe Ho Pie can be found in Sino-Malay newspapers and Mandarin teaching books used in Chinese schools (Fig. 7.2).

Most examples in Chun's Hoa Woe Ho Pie are specific to the experiences of the Indies Chinese. Its conversations generally take place in Batavia and specifically in the neighbourhood Pasar Baroe 'New Bazaar', which feature in the book as respectively Pa ta wei 巴達維 (Bādáwéi) or Pa tjeng 巴城 (Bāchéng) and Sen pa sa 新巴杀 (Xīnbāshā) 'New Bazaar'. In the introduction, Chun Foo Chun underscores the importance of a book about the Mandarin language:

I have indeed deliberately written this book for the needs of all you Sirs, who only understand, or know, the shape of Chinese characters, but do not understand what they mean; in this book all of their meanings will become clear; I have divided all that is written in Hoa Woe Ho Pie into four separate books. ${ }^{12}$

Of these four volumes, only the first has been preserved. ${ }^{13}$ The example sentences of Part One consist of various topics for everyday dialogues. The second volume reportedly focuses on interactions with important people, business talk, and domestic affairs. The third volume delves into Chinese characters with deeper meanings and their use in conversations, whereas the fourth volume deals with written correspondence. While the book was published by Chun Lim \&Co in Batavia, it was printed in China:

This book is of great necessity to obtain for you students in the Netherlands Indies, and for you Sirs who would like to know languages and should also know your own language.

If any Malay letter is misspelled, I offer my sincere apologies, as this book has been printed by typesetters in Shanghai, none of whom can speak Malay. ${ }^{14}$

12 Saia sengadja mengarang ini boekoe memangnja boeat keparloean pada L.W. Sian seng, jang tjoema mengarti, atawa kenal, sadja roepanja hoeroep tjina, tetapi tida tahoe menartinja, di dalam ini boekoe bisa menarangkan sekalian maksoednja, soerat jang ada tertoelis di dalam ini Hoa Woe Ho Pie, semoea saja pitjah 4 kepeng boekoe (Chun 1920: ii).

13 The only copy known to me is kept at the Leiden University Library.

14 Ini boekoe ada besar kaperloean boeat di mempoenjain oleh liatwi Hakseng 2 di hindia, balanda [sic!] ini dan boeat liatwi sian seng jang ada hati kapingin tahoe bahasa dan 


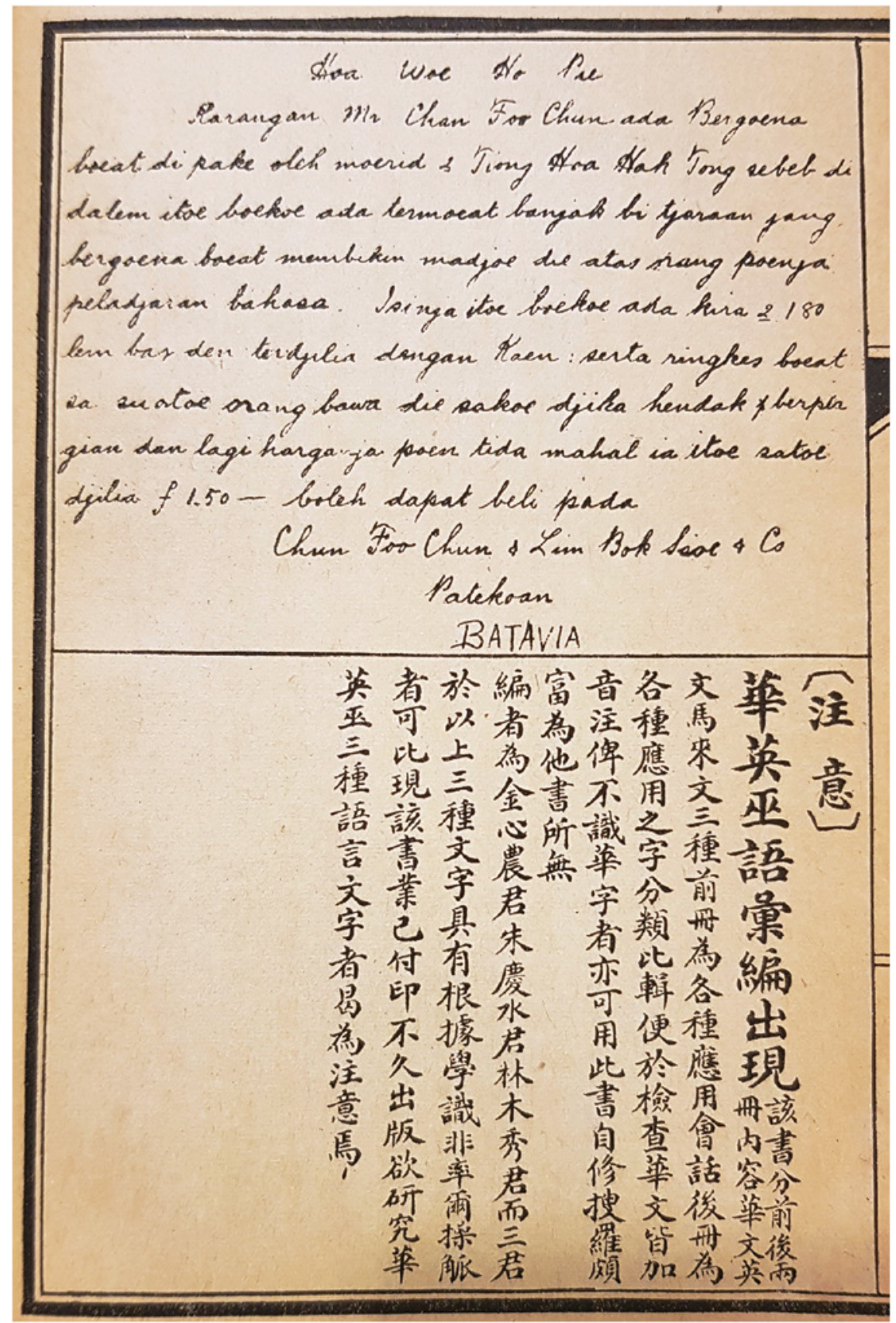

FIGURE 7.2 A hand-written advertisement of Hoa Woe Ho Pie

LEIDEN UNIVERSITY LIBRARY SINOL. 153236. NO KNOWN COPYRIGHT HOLDERS 
The fourth book examined in detail here is Kuo-Yü Zonder Goeroe 'Mandarin without a Teacher', published in 1934 by a certain Mrs. The (Fig. 7.3). ${ }^{15}$ Born in 1916, the author worked as a private Chinese teacher in Surabaya from the mid-193os. Her Kuo-Yü Zonder Goeroe, however, was intended for selfstudy. It was published by the Surabaya-based accountancy firm New China 新中華, founded in 1926 by her husband The Chung Shen 鄭叢森. In 1937, as several Netherlands Indies newspapers inform us, this Mandarin course was broadcasted across Central and East Java by the Netherlands Indies Radio Broadcasting Corporation (NIROM ). A second volume of Kuo-YüZonder Goeroe appeared in 1940. In 1941, Mrs. The's course appeared in parts in Eh Thoeng 兒童 'Child', a journal for Dutch-speaking young Chinese. In 1942, she also published a teaching book on the Chinese alphabet titled The National Alphabet for Overseas Chinese. ${ }^{16}$

In post-independence Indonesia, Mrs. The worked with her husband at the Lian Huo 聯合 High School and at his printing house in Surabaya, which published three newspapers: Chinese Daily News (in Chinese), De Vrije Pers (in Dutch), and Java Post (in Indonesian). ${ }^{17}$ In 1953, Indonesia-based Dutch newspapers report that she visited western Europe to study women in journalism. The couple's journalistic career faced a major setback in 1956, when their office was vandalized by a mob, leading to widely reported protests by Indonesian journalists. Their newspaper Java Post, which still exists today as Jawa Pos, proved most durable. Mrs. The had adopted the Indonesian name Mega Endah - and her husband became Suseno Tedjo - yet remained affectionately known as Tante The 'Auntie The' (Wangkar 2001: 15). In addition to the pro-ROC stance she evidently adopted sometime between the first and second volume of Kuo-Yü Zonder Goeroe, she quickly embraced the Indonesian nation-state and dedicated the rest of her career to the Jawa Pos. In the early 1980s, when her husband was in his late 70 and their three children had moved to Europe, she effectively managed this newspaper on her own (Iskan 1982: 28).

bahasa sendiri poen perloe djoega. | Kaloe salah swatoe hoeroep melajoe ada tersalah, saia banjak minta maaf sebab ini boekoe di tjitak di Sianghay leter zetter semoa tida tahoe omong melajoe (Chun 1920: iv).

15 Chinese: 鄭夫人, Malay: Njonja The. Her full name was Mrs. The Chung Shen-Tjia 鄭叢 森夫人.

16 Malay: Boekoe beladjar alphabet Kuo-Yin, Chinese: 華僑國音字母拼音法.

17 From 1948, Chinese Daily News was known as Hua Chiao Sin Wen or Hwa Chiau Hsin Wen 華僑新聞 'Overseas Chinese News'. At the time it was published, it was said to be Indonesia's only newspaper in Chinese that was politically pro-Indonesian (Iskan 1982: 28). De Vrije Pers ('The Free Press') was eventually renamed to Indonesian Daily News. 


\section{2 \\ 6. $f 2.60$ \\ KUO - YÜ ZONDER GOEROE}

SYSTEEM 1000 HOEROEF DENGEN DITERANGKEN DALEM BAHASA BELANDA DAN MELAJOE.

Djilid ka I.

DKKARANG OLEH :

Mevr. THE CHUNG SHEN - TJIA

TJITAKAN KA-AMPAT

SEPTEMBER 1940

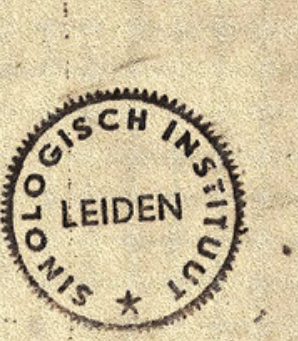

DITERBITKEN OLEH :

N. V. AGCOUNTANTSKANTOOR NEW GHINA SOERABA IA - JA YA.

FIGURE 7.3 Cover of Kuo-Yü Zonder Goeroe

LEIDEN UNIVERSITY LIBRARY. NO KNOWN COPYRIGHT HOLDERS 
In the first part of Kuo-YüZonder Goeroe, Mrs. The explains that Chinese, like Malay, has less morphology than European languages and is therefore easier to learn. For this book, she developed her own method to learn Mandarin, which required the student to learn the pronunciation of individual characters before having to study their usage in combinations, peruse example sentences, and carry out exercises. To indicate how Chinese characters should be pronounced, Mrs. The used a Dutch-influenced Indies-style romanization alongside Zhùyīn Fúhào transcriptions. In the second part of Kuo-Yü Zonder Goeroe, conversely, the entire source text - rather than just the individual characters at the beginning of each chapter - was given in romanized form underneath the Chinese characters. Part Two is remarkably more ideological in nature; it discusses trips to China and the embarrassment of ethnic Chinese who cannot understand "their own language". Several example sentences also mention Toean Cheng or Chĕng hsiën shĕng 鄭先生, clearly referring to Mrs. The's husband.

The above publications are by no means Indonesia's only educational texts on Mandarin. Next to the aforementioned exclusively Chinese materials, several small Mandarin-Malay dictionaries appeared from the 1910s onwards. One example is the Chinese-Malay Dictionary or Han Woe Tzi Tian 漢巫辭典, published in 1915 by the Batavia-based printing house Kho Tjeng Bie 高正美. Among its compilers are listed: Eric H. Tshen of the Republican University in Shanghai, Oey Tjiang Hoay 黃昌懷 from Hamburg, and the aforementioned Lim Bok Sioe from Batavia. Chun Foo Chun is also thanked in the introduction. A Mandarin-Malay-Dutch-English dictionary titled A Classified Dictionary of Chinese-Malay-Dutch-English with Chinese Pronounciation [sic! ${ }^{18}$ was published in 1931 by the National Book Office 國民書局 in Batavia. Its compiler Li Joek Koey 李毓愷 published several more lexicographical works in the 1950s and 196os. A third dictionary, the New Chinese-Malay Dictionary, ${ }_{19}^{19}$ appeared in 1935 by the hands of the aforementioned Oey Tjiang Hoay, by then a Semarang-based entrepreneur.

In November 1945, Yoe Wan Fei published another Mandarin self-study book titled Lim's Mandarin without a Teacher, ${ }^{20}$ once again encouraging Indonesia's Chinese community to learn the language and script of their "real" country. Among its targeted readership, as the introduction makes clear, were people

18 Chinese: 綜合華巫荷英大辭典: 國語注音; Malay: Kitab-logat jang mengatoerken dari bahasa-Tionghoa-Melajoe-Olanda-Inggris dengan soeara batjanja dalem bahasaTionghoa; Dutch: Chineesch-Maleisch-Hollandsch-Engelsch classificeerend-woordenboek met Chineesche uitspraak.

19 Chinese: 四角號碼華巫新辭典, Malay: Kitab Logat Baroe Tionghoa Melajoe.

20 Chinese: 林民國語自修讀本, Malay: Lim's Boekoe Peladjaran Kuo-YüZ Zonder Goeroe. The only copy known to me is kept at the Leiden University Library. 
who had learned some Mandarin at the Chinese elementary school - an institution designated with the curious Hokkien-Mandarin compound tjoe-têng siao-hsüeh (chiün-tñg 上堂 and xiǎoxué 小學) - but did not have a chance to further their education. Published in Jakarta (formerly Batavia) by Lim's Boekhandel, all the book's dialogues take place in China. Very little is known to me about the author, who also occasionally wrote about ancient Chinese history in the aforementioned periodical Sin Po.

\section{$3 \quad$ Mandarin, but Which Kind?}

From the mid-nineteenth century, Malay newspapers in the Netherlands Indies used a Dutch-influenced Indies-style romanization, rather than the Arabic-derived script in which native Malay speakers wrote their language. While far from consistently applied, these conventions were in broad use, especially in Java's cities. A similar system emerged almost organically for Mandarin when the need to transcribe it first arose. Some of its most salient characteristics are outlined in Table 7.1:

TABLE 7.1 The Indies-style transcription of Mandarin

\begin{tabular}{|c|c|c|}
\hline Romanization & Phonological value & Example \\
\hline ai, aij, aj, ay & /ai/ & tsai, tsaij, tsaj, tsay 在 (zài) \\
\hline ao, au, auw, aw & $\mid \mathrm{au} /$ & yao, yau, yauw, yaw 要 (yào) \\
\hline dj & $|\bar{d} 3| \sim|z|$ & djan 然 (rán) \\
\hline e, ê, ë, ĕ, ẽ & $|a|$ & hen, hên, hën, hĕn 很 (hěn) \\
\hline é, ee & $/ \mathrm{e} / \sim / \mathrm{ei} /$ & tjé, tjee 這 (zhèi) \\
\hline è, èh & $|\varepsilon|$ & hsüè, hsüèh 血 (xuè) \\
\hline$\hat{\mathrm{e}}, \mathrm{i}, \mathrm{u}$ & | 1 & tzê, tzi, tzŭ 子 (zi) \\
\hline euw, eoe & /rus $/$ & tjeuw, tjeoe 走 (zǒu) \\
\hline ie, ieh, i, î & $\mid \mathrm{i} /$ & tie, tieh, ti, tî 的 (dì) \\
\hline ni, nj & $/ \mathrm{ni} / \sim / \mathrm{n} /$ & niauw, njiauw 鳥 (niǎo) \\
\hline o, ô, òh & $|\mathrm{o}|$ & kwo, kwô, kwòh 國 (guó) \\
\hline oe, oo & $|\mathrm{u} / \sim| \mathrm{v} \mid$ & sioeng, hsioong 兄 (xiōng) \\
\hline oo, o & $10 /$ & tjoo, tjo 作 (zuò) \\
\hline oouw, ouw, ou & /oun/ & thoouw, thouw, thou 頭 (tóu) \\
\hline sj & $|\mathrm{J} / \sim| \mathrm{s} \mid$ & sjan 山 (shān) \\
\hline $\mathrm{tj}$ & $\left|\mathrm{t}_{6}\right| \sim\left|\mathrm{t}_{\mathrm{S}}\right|$ & tjoeng 中 (zhōng) \\
\hline$\ddot{\mathrm{u}}, \mathrm{uu}$ & $|y|$ & hsü, hsuu 許 (xǔ) \\
\hline
\end{tabular}


In the above system, the $\langle\mathrm{h}\rangle$ was used to mark aspirated consonants, e.g. khoeng 孔 (kǒng), phei 陪 (péi), tha 他 (tā), and tjha 茶 (chá), although this was not always done consistently or correctly. ${ }^{21}$ Vowel diacritics conveyed additional phonological detail; the diaeresis $\langle\ddot{\phi}\rangle$ indicated that the underlying vowel formed a distinct phonological unit, e.g. sjoeï 誰 (shuí), tjië 街 (jiē), and tjoöe 稠 (chóu). Other authors preferred the acute accent $\langle\dot{\rangle}\rangle$ for this purpose. Some orthographic idiosyncrasies indeed depended on individual preferences. Chun's Hoa Woe Ho Pie, for instance, frequently used $\langle\mathrm{v}\rangle$ to transcribe the sound /f/. The transcription of Mandarin onglides was also inconsistent; $y \bar{\imath}$ - can be found as $i$, ie, or $y i$, wù 惡 as oe, oeh, or woe, and yù 預 as $\ddot{u}$, üh, or $y \ddot{u}$. The Mandarin retroflex $(/ / / \sim / z /)$ was spelled as $\langle\mathrm{yr}\rangle$ word-initially but $\langle\mathrm{rl}\rangle$ word-finally by Chu et al. (1912), as $\langle\mathrm{jr}\rangle$ or $\langle\mathrm{j}\rangle$ word-initially and $\langle\mathrm{rl}\rangle$ wordfinally by Mrs. The (Shen-Tjia 1934), and as $\langle\mathrm{dz}\rangle$ or $\langle\mathrm{dj}\rangle$ word-initially and $\langle\mathrm{l}\rangle$ word-finally by Chun Foo Chun (1920). Fei (1945) transcribed it as $\langle\mathrm{r}\rangle$, but clarified in his preface that it "has to be voiced, with the tongue curled upwards". 22 The first volume of Kuo-Yü Zonder Goeroe transcribed Mandarin words as in Table 7.1, yet the second volume adopted a system closer to the Wade-Giles Romanization. ${ }^{23}$

Another source of complication was the inability of most ChineseIndonesians - in the good company of numerous speakers in China and Southeast Asia - to pronounce retroflex consonants. Dental, palatal, and retroflex consonants are often merged in the Mandarin of Java-born Chinese (Oetomo 1987: 81). This merger seems to have existed in late-colonial times too, judging from the identical way these sounds were transcribed. In early Malay textbooks, the voiceless alveolar sibilant affricate $/ \mathrm{ts} /\langle z\rangle$, the voiceless alveolo-palatal sibilant affricate $\left|\epsilon_{6}\right|\langle j\rangle$, and the voiceless retroflex sibilant affricate $/ \widehat{\widehat{s}} /\langle\mathrm{zh}\rangle$ were all routinely transcribed as $\langle\mathrm{t} j\rangle$, although the former was also sometimes transcribed as $\langle\mathrm{tz}\rangle,\langle\mathrm{ts}\rangle$, or $\langle\mathrm{tjz}\rangle$. Likewise, the aspirated voiceless alveolar affricate $/ \mathrm{ts}^{\mathrm{h}} /\langle\mathrm{c}\rangle$, the aspirated voiceless alveolo-palatal sibilant affricate $/ \widehat{\epsilon}_{6} \mathrm{~h} /\langle\mathrm{q}\rangle$, and the aspirated voiceless retroflex sibilant affricate $/ \mathbb{T}^{\mathrm{h}} /$ $\langle\mathrm{ch}\rangle$ were all transcribed as $\langle\mathrm{t} \mathrm{jh}\rangle$. The Dutch romanization was furthermore unable to accurately reflect the Mandarin sibilants, as was already pointed out by the aforementioned Nio Joe Lan in the 1930s (Nio 1933: 412). The orthographic $\langle\mathrm{s}\rangle$ was used for the voiceless alveolar dental sibilant $/ \mathrm{s} /$, the voiceless

21 The Philippine Hokkien data in Chia (this volume) are similar in this regard.

$22[\ldots]$ haroes diboenjiken satengah soeara, dengen lida ditekoek ka atas.

23 Dutch Sinologists, conversely, had their own way of transcribing northern Mandarin, in addition to having to know the French, English, and German systems (cf. Kuiper 2017: 100). Unlike Mrs. The's system, the Dutch Sinologists used diacritic markers to indicate tones. 
alveolo-palatal sibilant $/ 6 /$, and the voiceless retroflex sibilant $/ \mathrm{s} /$, corresponding respectively to $\langle\mathrm{s}\rangle,\langle\mathrm{x}\rangle$, and $\langle\mathrm{sh}\rangle$ in modern Mandarin. However, $/ \mathrm{c} /$ was also occasionally transcribed as $\langle\mathrm{hs}\rangle$, and $/ \mathrm{s} /$ as $\langle\mathrm{sch}\rangle,\langle\mathrm{sh}\rangle$, or $\langle\mathrm{sz}\rangle$.

The fact that the first volume of Kuo-Yü Zonder Goeroe gives Zhùyinn Fúhào transcriptions alongside Indies-style romanizations affords some further insights into the way Mandarin was pronounced. Syllables ending in $\langle\mid L\rangle$, which would suggest the pronunciation/iəy/, are consistently spelled as $\langle\mathrm{ing}\rangle$ in the Indies-style romanization. This implies that the orthographic schwa was not supposed to be pronounced in this context. This situation resembles that of contemporary Taiwan, where the historically common pronunciation of /iəy/ is considered uneducated or non-standard and $\langle\mathrm{i} \eta\rangle$ is systematically taught at schools (Li 2004: 115). For the syllabic consonant/क/, the Zhùyin Fúhào transcription implied that the characters 只, 址, 枝, 織, and 知 had to be pronounced identically as $\langle$ 出 $\rangle /$ 邻 $/$, yet in the Indies-style romanization they were spelled respectively as $t j i, t s \hat{e}, t s \breve{u}, t z \hat{e}$, and $t z \breve{u}$. It is difficult to determine whether this discrepancy reflects the inability of the Indies-style romanization to accurately reflect the sounds of Indonesian Mandarin, or of the Zhùyin Fúhào system to accurately reflect its minute phonological differences.

With diacritics already serving other purposes, the Indies-style romanization was unable to mark tones. Only the first volume of Kuo-Yü Zonder Goeroe contains information about tones. We can see the same four tones as in modern Mandarin; the fifth 'checked' tone of some earlier standardizations is absent. ${ }^{24}$ As the tones were given for each syllable individually, the book contains no indication of a neutral tone, as attested in modern Mandarin from mainland China (but not Taiwan). Even the particles le 了 (le) and $t z \breve{u}$ 子 (zi) were listed as carrying the third tone. The other three textbooks consistently spelled the particles $t i$ 的 (di $\sim$ de), liao 了 (liao le), and $n i$ 呢 (ni $\sim$ ne) in their "full" rather than unstressed "schwa" forms. In Chun's Hoa Woe Ho Pie, we can occasionally observe an orthographic $\langle\mathrm{h}\rangle$ marking the falling tone, e.g. mhai 賣 (mài) 'to sell' vs. mei 買 (măi) 'to buy' and nah lie 那裡 (nàlı̌) 'there' vs. na lie 哪裡 (nǎlǐ) 'where', but this usage is not consistent. In fact, the author contended that proper pronunciation could only be learned through conversation, although he remained open to feedback from his readers on this matter:

As has been said previously, this book does not use tone-indicating letters as this would increase the burden on its user - this is done in most books, adding to the confusion of the learner - because to teach pronunciation requires continuous familiarization with speech in order to 
quickly soften the tongue, alongside attention to easy, difficult, long, and short conversations, so that the listener will be able to understand them quickly; this is the most important thing, but in this book I will try to do a bit of both. You students may consider for yourselves what works best, and please let me know your thoughts, so that the third print can be adjusted to what most people want. ${ }^{25}$

Another complication was the aforementioned coexistence of a northern and a southern variety of Mandarin, known under different names. In Knoetsen's East Asia, they were introduced as Kiangsoe 江蘇 and Pitjili 北直隸 Mandarin, i.e. the Jiangsu (Nanjing area) and North Zhili (Beijing area) varieties. Knoetsen's summary of their sound correspondences is given in Table 7.2 (he provides no characters or examples). Throughout his dictionary, both pronunciations are juxtaposed if different.

TABLE 7.2 Kiangsoe 江蘇 and Pitjili 北直隸 correspondences

\begin{tabular}{ll}
\hline Kiangsoe & Pitjili \\
\hline eo & ou \\
kuu & tjuu \\
khuu & tjhuu \\
ki & tji \\
khi & tjhi \\
r & dj \\
o & oe \\
oei & eeï \\
ioo & oéé \\
\hline
\end{tabular}

DATA FROM KNOETSEN (1912: IV)

25 Seperti soedah dibilang tadi ini boekoe tida memake hoeroep pemantes swara memang djoega djadi lebeh membratkan kapada jang memake, begitoelah boekoe ${ }^{2}$ jang kebanjakakkan hingga menambah bingoengnja jang adjar, sebab adjar omong perloe sadja saban waktoe di biasaken beromong ${ }^{2}$ djadi lidah lekas lembek dan perhatikan djoega omongan jang enteng atawa brat pandjang atawa pendek, djadi bisa lekas mengarti orang jang mendengar, itoe jang paling perloe, tetapi di boekoe ini saia tjoba djoega tjampoer sedikit. Liatwi siangseng boleh timbang sendiri jang mana dikira baek harap di kabari sedikit pada saia, soepaia tjapan jang katiga bisa tjoetjoek menoeroet kemaoean orang banjak (Chun 1920: 101). 
In the second volume of Kuo-Yü Zonder Goeroe, it is clarified that the Mandarin of northern China - Pe-fang kuo-yü 北方國語 - will be used. As the author explains, this is the pronunciation of Beiping 北平. ${ }^{26}$ Nevertheless, she also calls attention to a number of archaic pronunciations that prevail among the Nanyang Chinese (Table 7.3). These, she explains, correspond with previously learned equivalents from the Mandarin of southern China:

TABLE 7.3 North Chinese and Nanyang correspondences according to Mrs. The

\begin{tabular}{llll}
\hline $\begin{array}{l}\text { Southern } \\
\text { Mandarin }\end{array}$ & $\begin{array}{l}\text { Northern } \\
\text { Mandarin }\end{array}$ & Character & Meaning \\
\hline ngo & wo & 我 (wǒ) & I \\
pe & pai & 白 (bái) & white \\
hsio & hsuéh & 學 (xué) & to learn \\
jin & rên & 人 (rén) & person \\
\hline
\end{tabular}

DATA FROM (SHEN-TJIA 1940: II)

In the first volume of Kuo-Yü Zonder Goeroe, too, we already find a predominance of northern Mandarin features. The rhotacization of syllable finals, for example, was (and is) more common in the Mandarin of Beijing than of Nanjing. ${ }^{27}$ We indeed encounter the forms na'rl 哪兒 (năr) 'where', tjê'rl 這兒 (zhèr) 'here', and yi tia'rl一點兒 (yīdiăr) 'a little'. In the Classified Conversations, too, these occur as na erl, tjee erl, and i tien erl.

The substitution of southern for northern Mandarin, however, was a gradual process. Yoe Wan Fei advised as late as 1945 that Mandarin 〈ou〉/oun/ had to be pronounced as in Sundanese: $\langle\mathrm{eu}\rangle / \gamma /$. This older pronunciation resembles that of southern Mandarin (Coblin 200o: 301, 327) and can also be seen in the other textbooks, e.g. theuw 頭 (tóu) 'head', tjeuw 走 (zǒu) 'to walk', and tjheoe 醜 (chǒu) 'ugly'. In other attested vocabulary, the $\langle\mathrm{ou}\rangle$ of standard Mandarin corresponds to the high back rounded vowel / $\mathrm{u} /$ in early Indonesian textbooks, e.g. pêng yoe 朋友 (péngyǒu) 'friend', toe 都 (dōu) 'all', and yoe 有 (yǒu) 'have'. Another feature seen in the textbooks is the innovation *wo $>0$, which took place in southern but not in northern Mandarin dialects (Coblin 2000: 317-18), e.g. sho or sòh 說 (shuō) 'to say', tjoh 錯 (cuò) 'wrong', and to 多 (duō) 'many'. We also frequently encounter a historically common $\langle\mathbf{0}\rangle$ where standard Mandarin

$26 \quad$ Beiping was the name of Beijing from 1928 to 1949.

27 This phonological process is known in Chinese linguistics as érhuà 兒化. 
now has 〈e〉, e.g. koh 割 (gē) 'to cut', kho ie 可以 (kěy̌r) 'can', and na ie ko 哪一個 (nayyigè) 'which one'. The latter two features remain common in the informal Mandarin of southern China and Taiwan. Some additional "pre-standardized" pronunciations are listed in Table 7.4:

TABLE 7.4 Archaic pronunciations in Indonesian Mandarin

\begin{tabular}{llll}
\hline Textbooks & Modern & Character & Meaning \\
\hline hê & hēi & 黑 & black \\
i & tā & 她a & she \\
ke $\sim$ kie & gěi & 給 & to give \\
loe & liù & 六 & six \\
mo & me & 麼 & PART \\
ngay & ăi & 矮 & short \\
ngô & è & 餓 & hungry \\
o & ā & 啊 & PART \\
pê & băi & 百 & hundred \\
po & běi & 北 & north \\
sê mo & shéme & 什麼 & what \\
sjoeï sooi $\sim$ swe & shéi $\sim$ shúi & 誰 & who \\
tho & tā & 牠 & it \\
tjia fei & kāfèi & 咖啡 & coffee \\
tjio & jiăo & 角 & 10 -cent coin \\
tjoey $\sim$ tjhu $\sim$ ki & qù & 去 & to go \\
\hline
\end{tabular}

a I have not come across the "expected" character 伊 $(y \bar{\imath})$ in the textbooks.

The textbooks also contain some currently non-standard (yet still widespread) vocabulary, e.g. li pai 禮拜 (lỉbài) 'week', tjhai $i$ 差役 (chāiyì) 'policeman', tji tjê 汽車 (qì̀chē) 'steam tram', and woe lai 巫來 (wūlái) 'Malay'. ${ }^{28}$ The word for 'don't' is poe-yau 不要 (bùyào) in Knoetsen (1912) and Mrs. The (Shen-Tjia 1934), but moyauw 莫要 (mòyào) in Chun (1920) and piêh 別 (bié) in Chu et al. (1912). East-Asia exhibits the words hang-sji 行市 (hángshi) 'market', moe-ju-kièn 沐浴間 (mùyùjiān) 'bathroom', and nioe-nai-joe 牛奶油 (niúnǎiyóu) 'butter', yet Kuo-Yü Zonder Goeroe - which came out roughly two decades later - gives

28 The present-day equivalents are xīngqi 星期, jǐngchá 星期, zhēngqi diànchē 蒸汽電車, and Mǎlái 馬來, while qìchē 汽車 currently refers to a 'car'. Evan Morgan's revised list of Chinese neologisms (1932) exhibits yet another word for 'policeman': xúntǔ 巡土. 
shang-tjang 商場 (shāngchăng), yu-fang 浴房 (yùfáng), and huang-yu 黃油 (huángyóu) for the same concepts. ${ }^{29}$ Similarly, Hoa Woe Ho Pie displays tjwo twa tjeg 腳踏車 (jiăotàchē) for 'bicycle', whereas Kuo-Yü Zonder Goeroe has tjiotjhê 脚車 (jiǎochē). While I have not come across any obvious non-standard characters, the material contains some "variant" characters (allographs), such as 箇 (ko) for the numeral classifier 個 (gè), 軲 (djoeaän) for 軟 (ruăn) 'soft', 裏 (lie) for 裡 (lí) 'inside', 那末 (na mo) for 那麼 (nàme) 'so', 甚麼 (shen mo) for 什麼 (shéme) 'what', and 洷 (zei) for 濕 (shī) 'wet'. All the textbooks use traditional characters, yet they feature a small number of shorthand variants, e.g. 华 ( $h w a$ ) for 華 (huá) 'Chinese', 脚 (tjio) for 腳 (jiǎo) 'foot', 巴杀 (pa sa) for 巴刹 (bāshā) 'market', and 雅致 (ya tzi) for 雅緻 (yǎzhì) 'elegant'.

The textbooks afford similar linguistic observations on the history of Malay. Earlier scholarship has underlined the importance of "the hybridized Malay-Hokkien vernacular" to the study of Mandarin in Indonesia (Sai 2016: 375; Hoogervorst 2021: 42-50). All the textbooks examined here are indeed written in a type of colloquial Malay saturated with Hokkien loanwords, which "behaved" similarly to Baba Malay (Aye, this volume) on a typological level. Yet because both the Malay and the Hokkien dialects differed from those in Malaya, the vernacular that is analysed below should be regarded as a distinct variety. Before delving into its Hokkien elements, it is important to first investigate the Malay itself as used by the Chinese in Java's late-colonial cities. As the primary lingua franca of maritime Southeast Asia, Malay was learned by Chinese visitors and settlers from at least early-modern times. The Netherlands Indies government likewise adopted Malay for administrative purposes, but used a standardization that was quite remote from what was actually spoken by the colony's urban middle-classes. The Mandarin textbooks investigated here all exhibit the Malay used in Java. Even Knoetsen, who must have learned his Malay in Sumatra, used words specific to Java. Table 7.5 below lists some common lexical items found in the Sino-Malay textbooks, along with their equivalents in the "standard" Malay promoted by the colonial government. The grammar of Java's urban Malay has been examined by previous scholars (Oetomo 1991; Mahdi 2016).

29 Cf. shichăng 市場 'market' and năiyóu 奶油 'butter' in Morgan (1932). 
TABLE 7.5 Common Java Malay words in the textbooks

\begin{tabular}{lll}
\hline Textbooks & Standard Malay & Meaning \\
\hline begimana, pigimana & bagaimana & how \\
belon tau & beloem pernah & never before \\
boto & tjantik & pretty \\
kaler & oetara & north \\
kasoesoe & terboeroe-boeroe & in a hurry \\
katjek & berbeda & different \\
kidoel & selatan & south \\
koedoe & haroes & must \\
koelon & barat & west \\
lantaran & sebab & because \\
lantas & segera & immediately \\
mama-tjang & nenek & grandmother \\
ngambang & terapoeng & to float \\
njang & jang & REL \\
papa-tjang & kakek & grandfather \\
perdio & tjoema-tjoema & free of charge \\
saban & setiap & each \\
wetan & timoer & east \\
\hline
\end{tabular}

While many Chinese-Indonesian families had lost fluency in Zhangzhou Hokkien or never spoke it to begin with, their colloquial Malay was permeated with "heritage words" from that language. These words were almost exclusively written in Indies-style romanization. For reasons of recognizability, however, I also give the corresponding Chinese characters and their modern transcriptions throughout this section. In addition to Hokkien loanwords that were widespread even among non-Chinese speakers of Malay - such as goea 我 (góa) 'I', loe 汝 (lú) 'you', taotjang 頭䦊 (thâu-chang) 'queue, pigtail', Tiongkok 中國 (tiong-kok) 'China', and Tionghoa 中華 (tiong-hoa) 'Chinese' - the textbooks commonly employ such terms as hakseng 學生 (hák-seng) 'student', haktong 學堂 (hák-tōng) 'school', liatwi 列位 (liát-ūi) 'all of you', and sedji 細淢 (sè-jī) 'cautious, polite'.

Even more importantly, Hokkien vocabulary was systematically relied upon to translate Mandarin words for which no Java Malay equivalents could 
be found. The Classified Conversations, for example, translates miên pao 麵包 (miànbāo) 'steamed bun', sing tjen 生辰 (shēngchén) 'birthday', soeng pin 送殯 (sòngbìn) 'funeral procession', and toeng yang tjê 東洋車 (dōngyángchē) 'rickshaw' with their Hokkien equivalents bapauw 肉包 (bah-pau), sejit 生日 ( $\mathrm{se}^{\mathrm{n}}$-jit), sangseng 送喪 (sàng-sng), and langtjia 人車 (lâng-chhia). Likewise, the second volume of Kuo-Yü Zonder Goeroe translates tja ts'ai 什菜 (shícài zácài) 'mixed vegetables' and tj'a hoe 茶壼 (cháhú) 'teapot' as tjap-tjai 雜菜 (chàp-chhài) and theeko 茶鈷 (tê-kó-), whereas Hoa Woe Ho Pie translates ta tjhoeen 打拳 (dǎ quán) 'boxing' and toe soe 讀書 (dú shū) 'to study' as koentaü 拳頭 (kûn-thâu) and taktje 讀冊 (thàk-chheh). For the expression koeng shi koeng shi 恭喜恭喜 (gōngxǐ gōngxǐ) 'congratulations!', he clarifies that the Hokkiens pronounce it as kiong hi kiong hi 恭喜恭喜 (kiong-hí kiong-hí). The Mandarin term joen toeng 運動 (yùndòng) 'to exercise' is left as such in Malay (Chun 1920: 59), seemingly because it was well known in Chinese-Indonesian circles. Table 7.6 lists some additional Hokkien-derived translations of Mandarin words attested in the textbooks:

TABLE 7.6 Common Hokkien translations of Mandarin words

\begin{tabular}{|c|c|c|}
\hline $\begin{array}{l}\text { Mandarin (as in } \\
\text { textbooks) }\end{array}$ & Sino-Malay & $\begin{array}{l}\text { Meaning (in } \\
\text { textbooks) }\end{array}$ \\
\hline ay ya 僾呀 (ài ya) & aya 哎呀 (ai-ia) & (exclamation) \\
\hline ho-shang 和尚 (héshàng) & hweeshio 和尚 (hôe-siōn) & Buddhist monk \\
\hline $\begin{array}{l}\text { hsién-koean 縣官 } \\
\text { (xiànguān) }\end{array}$ & tikoan 知縣 (ti-koān) & district governor \\
\hline hsi-thién 西天 (xītiān) & saythi 西天 (sai-thin) & Heaven \\
\hline khoeng tze 孔子 (kǒngzǐ) & $\begin{array}{l}\text { khong hoe tjoe 孔夫子 } \\
\text { (khóng-hu-chú) }\end{array}$ & Confucius \\
\hline mê 墨 (mò) & bak 墨 (bảk) & ink \\
\hline $\begin{array}{l}\text { Nam Jang 南洋 (nányáng) } \\
\text { pî 筆 (bǐ) }\end{array}$ & $\begin{array}{l}\text { Lam Yang 南洋 (lâm-yâng) } \\
\text { pit 筆 (pit) }\end{array}$ & $\begin{array}{l}\text { Southeast Asia } \\
\text { brush pen }\end{array}$ \\
\hline siën sen 先生 (xiānshēng) & sianseng 先生 (sian-seng) & Sir \\
\hline sing 姓 (xìng) & $\operatorname{she}^{\mathrm{n}}$ 姓 $\left(\mathrm{sèn}^{\mathrm{n}}\right)$ & family name \\
\hline soe 素 (sù) & tjiatjaj 食齋 (chiảh-chai) & vegetarian \\
\hline toeng tjia 東家 (dōng jiā) & tauwké, toke 頭家 (thâu-ke) & head of a business \\
\hline wan seng 晚生 (wǎnshēng) & boan seng 晚生 (bóan-seng) & I (self-deprecatory) \\
\hline
\end{tabular}




\section{楼自己家中人 \\ Panggilan dalam roemah sendiri poenja orang}

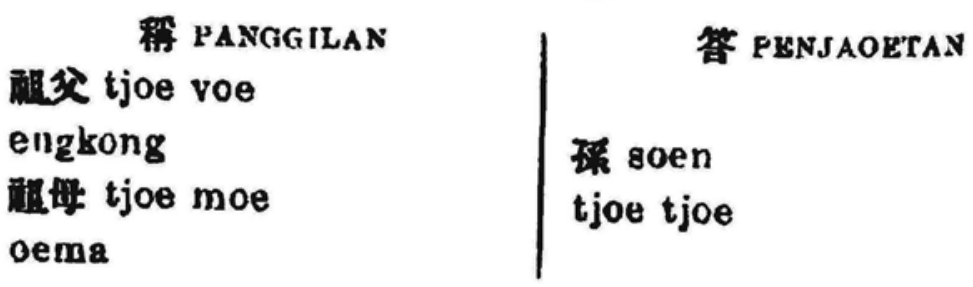

尖親 voe tjing

papa

恶魏 moe tjing

mama
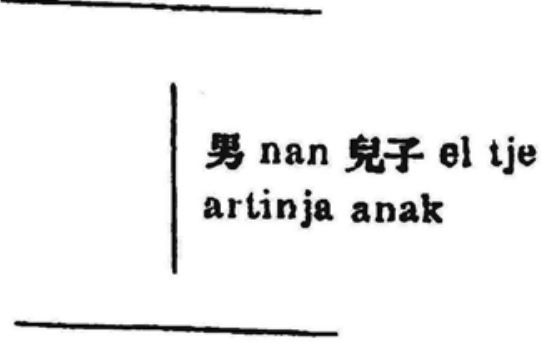

哥需 ko ko engko

增婛 saw saw

enso

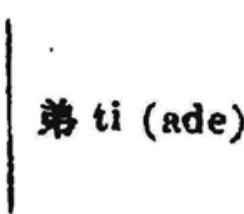

FIGURE 7.4 An explanation of kinship terms in Hoa Woe Ho Pie CHUN FOO CHUN, HOA WOE HO PIE (BATAVIA: CHUN LIM \&CO, 1920). NO KNOWN COPYRIGHT HOLDERS

Most Mandarin words for the names of family members, too, lacked precise Malay equivalents. Fortunately, many Chinese-Indonesian families still used the corresponding Hokkien terms, even when their dominant language had shifted to Malay (Fig. 7.4). For the designation of maternal cousins and their children, for example, the Mandarin element piaw 表 (biăo) corresponded perfectly to Hokkien piaw 表 (piáu). For siblings from the same paternal clan, Mandarin thang 堂 (táng) corresponded to Hokkien tong 堂 (tông).

Table 7.7 lists additional Mandarin kinship terms and their Hokkien/SinoMalay translations, based on lists given in two of the textbooks (Chun 1920: 104-14; Shen-Tjia 1934: 245): 
TABLE 7.7 Mandarin kinship terms and their Sino-Malay glosses

\begin{tabular}{|c|c|c|}
\hline Mandarin & Sino-Malay & English gloss \\
\hline ko ko 哥哥 (gēgē) & engkoh 俺哥 (ńg-ko) & older brother \\
\hline koe moe 姑母 (gūmǔ) & kòh 姑 (ko·) & paternal aunt \\
\hline koe tjang 姑丈 (gūzhàng) & kò-tio 姑丈 (ko-tiōon $)$ & husband of paternal aunt \\
\hline law pee 老伯 (lǎobó) & empee 俺伯 (ńg-peh) & older paternal uncle \\
\hline law sioeng 老兄 (lǎoxiōng) & engkoh 俺哥 (ńg-ko) & older brother \\
\hline law soe 老叔 (lǎoshū) & intjek 俺叔 (ńg-chek) & younger paternal uncle \\
\hline pen tjia 本家 (běnjiā) & tjinlang 親人 (chhin-lâng) & distant relative \\
\hline po foe 伯父 (bófù) & empe 俺伯 (ńg-peh) & older paternal uncle \\
\hline saw saw 嫂嫂 (sǎosăo) & enso 俺嫂 (ńg-só) & older brother's wife \\
\hline shen moe 嬸母 (shěnmǔ) & entjim 俺嬸 (ńg-chím) & $\begin{array}{l}\text { wife of younger paternal } \\
\text { uncle }\end{array}$ \\
\hline shoe foe 叔父 (shūfü) & entjek 俺叔 (ńg-chek) & younger paternal uncle \\
\hline shoe moe 叔母 (shūmǔ) & entjim 俺嬸 (ńg-chím) & $\begin{array}{l}\text { wife of younger paternal } \\
\text { uncle }\end{array}$ \\
\hline siong 兄 (xiōng) & engkoh 俺哥 (ńg-ko) & older brother \\
\hline ta koe 大姑 (dàgū) & kòh 姑 (ko·) & older paternal aunt \\
\hline ta yi 大姨 (dàyí) & toa-i 大姨 (tōa-î̀) & older maternal aunt \\
\hline tang saw 堂嫂 (tángsǎo) & $\begin{array}{l}\text { tong hia so 堂兄嫂 } \\
\text { (tông-hia }{ }^{\text {-só }} \text { ) }\end{array}$ & $\begin{array}{l}\text { wife of older brother of the } \\
\text { same clan }\end{array}$ \\
\hline $\begin{array}{l}\text { tang sioeng 堂兄 } \\
\text { (tángxiōng) }\end{array}$ & tong hia 堂兄 (tông-hia ${ }^{\mathrm{n}}$ ) & $\begin{array}{l}\text { older brother of the same } \\
\text { clan }\end{array}$ \\
\hline tang ti 堂弟 (tángdì) & tong te 堂弟 (tông-tē) & $\begin{array}{l}\text { younger paternal male } \\
\text { cousin }\end{array}$ \\
\hline tang ti foe 堂弟婦 & tong te poe 堂弟婦 & younger paternal female \\
\hline (tángdìfù) & (tông-tē-pū) & cousin \\
\hline $\begin{array}{l}\text { tjêng tjoe foe 曾祖父 } \\
\text { (zēngzǔfù) }\end{array}$ & kongtjo 公祖 (kong-chó·) & paternal great-grandfather \\
\hline $\begin{array}{l}\text { tjêng tjoe moe 曾祖母 } \\
\text { (zēngzǔmǔ) }\end{array}$ & ma'tjo 媽祖 (má-chó·) & paternal great-grandmother \\
\hline tjie tjie 姐姐 (jiějiě) & intji 俺姊 (ńg-chí) & older sister \\
\hline tjioe foe 舅父 (jiù fù) & engkoe 俺舅 (ńg-kū) & maternal uncle \\
\hline tjoe foe 祖父 (zǔfù) & engkong 俺公 (ńg-kong) & paternal grandfather \\
\hline yi moe 姨母 (yímǔ) & ie 姨 $(\hat{\imath})$ & maternal aunt \\
\hline yi tjang 姨丈 (yízhàng) & ie-tio 姨丈 $\left(\hat{\mathrm{i}}-\mathrm{tio} \bar{o}^{\mathrm{n}}\right)$ & husband of maternal aunt \\
\hline
\end{tabular}


TABLE 7.8 Mandarin dictionary entries and their Sino-Malay glosses

\begin{tabular}{lll}
\hline Mandarin & Sino-Malay & English gloss \\
\hline kan-lang 橄欖 (gănlǎn) & kana 橄欖 (kan'-ná) & Chinese olive \\
kan-tso 甘草 (gāncăo) & kamtjo 甘草 (kam-chhó) & liquorice root \\
ko-le-shen 高麗參 (gāolíshēn) & kolesom 高麗參 (ko-lê-som) & ginseng \\
kung-shi 公司 (gōngsī) & kongsie 公司 (kong-si) & company \\
kwa-tse 瓜子 (guāzǐ) & kwatji 瓜子 (koa-chí) & melon seeds \\
li 梨 (lí) & boeah laij (buah 'fruit' + 梨 lâi) & pear \\
liu-zun-yin 呂宋煙 (lüsòng yān) & lisong 呂宋 (lī-sòng) & Luzon cigarettes \\
lung-yian 龍眼 (lóngyǎn) & lengkeng 龍眼 (lêng-kéng) & longan fruit \\
ma-feng 麻風 (máfēng) & taij-ko 癩哥 (thái-ko) & leprosy \\
mah-tsio 麻雀 (máquè) & mah-tjiok 麻雀 (mâ-chhiok) & mahjong \\
pian-sin-pu-soei 半身不遂 & piansoei 半遂 (piàn-sūi) & paralysis \\
(bànshēn bùsuí) & & \\
sheng-jih 生日 (shēngrì) & she-djit 生日 (se ${ }^{n}$-jit) & birthday \\
tau-yia 豆芽 (dòuyá) & tauge 豆芽 (tāu-gê) & bean sprouts \\
thaw 桃 (táo) & sianto 仙桃 (sian-thô) & peach \\
yang-mei 楊梅 (yángméi) & yangbwee 楊梅 (iâng-bôe) & syphilis \\
\hline
\end{tabular}

DATA TAKEN FROM LI (1931)

We see the same phenomenon in Li Joek Koey's 1931 Mandarin-MalayDutch-English dictionary, in which several "Malay" glosses of Mandarin entries are likewise Hokkien-derived (Table 7.8). In addition, a small number of glosses come from other Sinitic varieties, e.g. pipah 'loquat', lobak 'daikon', sumok 'sappanwood', and tzifa 'persimmon flower', respectively from Mandarin pípá 枇杷, Cantonese $l o^{4}$ baak 6 蘿葍, Hakka sh-muk 蘇木, and Hakka chhu-fâ 柿花.

In some textbooks, the Malay glosses reveal grammatical influence from the Chinese source text on account of their atypical idiom. The sentence Tjé lie ti tjië tao hĕn kan tjing 這裡的街道很乾净 'The roads here are very clean', for example, is translated into Malay as Disini poenja djalanan bersi sekali (Shen-Tjia 1940:114-15), rather than Djalanan disini bersi sekali. Chun Foo Chun in particular had a tendency to translate Chinese idioms literally into Malay. Thus, khan soe 看書 (kànshū) 'to read', ming pê 明白 (míngbai) 'to understand', ta seng 大聲 (dàshēng) 'loud', and tjo tje 坐車 (zuòchē) 'to take a car' become respectively liat boekoe 'to see books', ngarti trang 'to understand clearly', swara besar 'big voice', and doedoek kereta 'to sit in a car'. For the verbal constructions 
tse jen 喫煙 (chīyān) 'to smoke', tse tjah 喫茶 (chīchá) 'to have tea', and tse tjioe 喫酒 (chijiǔ) 'to have alcohol', Chun's Malay translations faithfully display makan roko 'to eat cigarettes', makan thee 'to eat tea', and makan arak 'to eat alcohol', even though the word minoem 'to drink' would have been more natural. In Mandarin itself, the usage of the verb for 'to eat' in such constructions is currently considered as "southern non-standard", possibly reflecting Chun's Hakka origins. Furthermore, the copulative verb sze 是 (shì) and the adjectival particle hen 很 (hěn) are consistently translated into Malay as respectively betoel 'indeed' and amat 'very', yielding awkward translations as both words can (and should) be omitted in idiomatic Malay. In other cases, Chun translates Mandarin terms with a short Malay description, e.g. joan toeng 圓通 (yuántōng) 'accommodating' as tida soeka kasi orang marah 'does not like to upset people' and tjhian koeng 謙恭 (qiāngōng) 'humble' as tida mata tingi kaja miskin sama rata 'is neither haughty nor distinguishes between rich and poor'.

\section{5 \\ Phrasing Chineseness}

Having investigated the linguistic peculiarities of both the Mandarin source language and the Sino-Malay target language, we now take a closer look at the contents of the textbooks. Language manuals and phrasebooks generally provide miscellaneous examples of the way power hierarchies and other social information are linguistically encoded. A plethora of European-authored Malay phrasebooks, for example, entered the markets of the Netherlands Indies and British Malaya from the late-nineteenth century, promising the prospective colonial servant, soldier, or tourist efficient ways to communicate with the "native population". This topic deserves a separate study and could fruitfully be connected to present-day Singaporean guidebooks on talking to (Indonesian and other) domestic workers. Malay phrasebooks intended for Chinese readers, too, have been discussed in more detail elsewhere (Hoogervorst 2021). In what follows, I will limit myself to the contents of Mandarin textbooks in Malay.

The Classified Conversations, which served to prepare Indies-born Chinese for a trip to China, contains many example sentences that take place in trams, trains, and boats. The phrasebook clearly aimed to portray the newly established ROC as a modern society. No better illustration can be given than the following selected sentences, given in the context of a Western-style dance party (Chu et al. 1912: 64-65): 


\begin{tabular}{|c|c|c|c|}
\hline 要我扶麼 & Yao wo foe mo? & $\begin{array}{l}\text { Shall I offer you my } \\
\text { arm? }\end{array}$ & $\begin{array}{l}\text { Bolehkah saja bri } \\
\text { tangan saja padamoe? } \\
\text { (toentoen) }\end{array}$ \\
\hline $\begin{array}{l}\text { 那些太太穿 } \\
\text { 的衣服很雅 } \\
\text { 致很清潔a }\end{array}$ & $\begin{array}{l}\text { Na see tai tai tjoan } \\
\text { tih i foeh hen ya tzi } \\
\text { hen tjiêh tjin }\end{array}$ & $\begin{array}{l}\text { The ladies are very } \\
\text { elegantly and neatly } \\
\text { dressed }\end{array}$ & $\begin{array}{l}\text { Njonja njonja berpake } \\
\text { amat baik dan rapi }\end{array}$ \\
\hline $\begin{array}{l}\text { 太太, 我可 } \\
\text { 以和你作方 } \\
\text { 形跳舞麼 }\end{array}$ & $\begin{array}{l}\text { Tai tai, wo koo i hoo } \\
\text { ni tjo fang sjing tiao } \\
\text { woe mo? }\end{array}$ & $\begin{array}{l}\text { May I have the plea- } \\
\text { sure of dancing this } \\
\text { quadrille with you, } \\
\text { Madam? }\end{array}$ & $\begin{array}{l}\text { Bole saja plesir dansa di } \\
\text { ini dansaan sama kau } \\
\text { njonja? }\end{array}$ \\
\hline $\begin{array}{l}\text { 跳舞叫我 } \\
\text { 頭量 }\end{array}$ & $\begin{array}{l}\text { Tiao woe tjhiao wo } \\
\text { thoouw yuen }\end{array}$ & $\begin{array}{l}\text { Walzing [sic!] makes } \\
\text { me giddy }\end{array}$ & $\begin{array}{l}\text { Dansa bikin saja } \\
\text { sempojongan }\end{array}$ \\
\hline $\begin{array}{l}\text { 我給你一杯 } \\
\text { 檸檬水 }\end{array}$ & $\begin{array}{l}\text { Wo kie ni i pei lin- } \\
\text { mon soei }\end{array}$ & $\begin{array}{l}\text { Allow me to offer you } \\
\text { a glass of lemonade }\end{array}$ & $\begin{array}{l}\text { Kasi saja permisi boeat } \\
\text { soegoeken kau satoe } \\
\text { glas limonade }\end{array}$ \\
\hline
\end{tabular}

a 清潔 (qīngjié) for tjiêh tjin should presumably have been 潔淨 (jiéjìng) in view of the pronunciation given. Both words could be translated with English 'clean' and/or Malay rapi.

Chun's Hoa Woe Ho Pie, with its focus on the Netherlands Indies, contains various example sentences in a classroom setting (Chun 1920: 134-37). These are clearly inspired by contemporaneous schoolbooks from China. A school teacher's explanation of the aphorism Sze noeng koeng sang tjiay ih tang ping 士, 農, 工, 商, 皆宜當兵 'scholars, farmers, laborers, and businessmen should all become soldiers', for example, can be traced back to a popular schoolbook from the Roc titled Mandarin Textbook 國語教科書, which was also used by Tiong Hoa Hwe Koan schools. ${ }^{30}$ Other example sentences in Hoa Woe Ho Pie confirm that a great nation should possess a great army. However, as the writer reassured, 'Java is a territory of the Netherlands': Tjauw wa sze ho lan kwô tî sôe $t i$ 爪哇, 是荷蘭國的屬地 (Chun 1920: 148). Notwithstanding Holland's political hegemony, however, the textbook left little doubt that the loyalty of the colony's Chinese population belonged to the Roc. The following questionsand-answers illustrate this point (Chun 1920: 120-21):31

\footnotetext{
30 Copies from the Netherlands Indies can be found at the Leiden University Library (Sinol. 153236). For more context, see Hou (2017).

31 Here and below, the translations into English are mine.
} 


\begin{tabular}{|c|c|c|c|}
\hline $\begin{array}{l}\text { 中國人, 不 } \\
\text { 讀中國書, 好 } \\
\text { 麼? }\end{array}$ & $\begin{array}{l}\text { Tjoeng kwo jin poe } \\
\text { toe tjoeng kwo soe } \\
\text { hao mo? }\end{array}$ & $\begin{array}{l}\text { orang tjina tidak seko- } \\
\text { lah tjina baik tida? }\end{array}$ & $\begin{array}{l}\text { 'Is it a good thing if } \\
\text { Chinese people do } \\
\text { not study China?' }\end{array}$ \\
\hline $\begin{array}{l}\text { 很不好, 很 } \\
\text { 差愧 }\end{array}$ & $\begin{array}{l}\text { Hen pu hao, hen } \\
\text { sioe khwe }\end{array}$ & $\begin{array}{l}\text { amat tida baik amat } \\
\text { maloe }\end{array}$ & $\begin{array}{l}\text { 'It's very bad, very } \\
\text { embarrassing' }\end{array}$ \\
\hline $\begin{array}{l}\text { 怎麼樣, 很 } \\
\text { 差愧? }\end{array}$ & $\begin{array}{l}\text { Tjan me jang hen } \\
\text { sioe khwe? }\end{array}$ & $\begin{array}{l}\text { bagi mana amat } \\
\text { maloe? }\end{array}$ & $\begin{array}{l}\text { 'Why is it very } \\
\text { embarrassing?' }\end{array}$ \\
\hline $\begin{array}{l}\text { 中國人, 不 } \\
\text { 讀中國書, } \\
\text { 不曉得中國 } \\
\text { 字, 很差愧 }\end{array}$ & $\begin{array}{l}\text { Tjoeng kwo jin poe } \\
\text { toe tjoeng kwo soe } \\
\text { poe siaw te tjoeng } \\
\text { kwo tze hen sioe } \\
\text { khwe }\end{array}$ & $\begin{array}{l}\text { orang tjina tida sekola } \\
\text { tjina tida taoe soerat } \\
\text { tjina amat maloe }\end{array}$ & $\begin{array}{l}\text { 'Chinese people who } \\
\text { do not study China } \\
\text { and cannot write } \\
\text { Chinese are very } \\
\text { embarrassing' }\end{array}$ \\
\hline $\begin{array}{l}\text { 不讀中國 } \\
\text { 書, 不曉得 } \\
\text { 講中國話, } \\
\text { 天天講馬來 } \\
\text { 話, 更差愧 }\end{array}$ & $\begin{array}{l}\text { Poe toe tjoeng kwo } \\
\text { soe, poe siaw te tjiang } \\
\text { tjoeng kwo wa, thin } \\
\text { thin tjiang ma le wa, } \\
\text { keng sioe khwe }\end{array}$ & $\begin{array}{l}\text { tida sekola tjina tida } \\
\text { taoe bitjara tjina hari } \\
\text { hari bitjara malajoe } \\
\text { lagi maloe }\end{array}$ & $\begin{array}{l}\text { 'Not studying China, } \\
\text { not being able to } \\
\text { speak Chinese, and } \\
\text { speaking Malay every } \\
\text { day is even more } \\
\text { embarrassing' }\end{array}$ \\
\hline $\begin{array}{l}\text { 你愛中國 } \\
\text { 麼? }\end{array}$ & Ni ay tjoeng kwo mo? & $\begin{array}{l}\text { loe tjinta negeri } \\
\text { tjina tida? }\end{array}$ & $\begin{array}{l}\text { 'Do you love China or } \\
\text { not?' }\end{array}$ \\
\hline $\begin{array}{l}\text { 我是中國 } \\
\text { 人, 我很愛 } \\
\text { 中國 }\end{array}$ & $\begin{array}{l}\text { Wo sze tjoeng kwo jin, } \\
\text { wo hen ay tjoeng kwo }\end{array}$ & $\begin{array}{l}\text { saia djadi orang } \\
\text { tjina saia amat tjinta } \\
\text { negeri tjina }\end{array}$ & $\begin{array}{l}\text { 'I'm Chinese, I love } \\
\text { China very much' }\end{array}$ \\
\hline $\begin{array}{l}\text { 你將來要去 } \\
\text { 中國麼 }\end{array}$ & $\begin{array}{l}\text { Ni tjiang le yaw tjoey } \\
\text { tjoeng kwo mo? }\end{array}$ & $\begin{array}{l}\text { loe nanti maoe pegi } \\
\text { negeri tjina tida? }\end{array}$ & $\begin{array}{l}\text { 'Do you want to go to } \\
\text { China in the future?' }\end{array}$ \\
\hline $\begin{array}{l}\text { 我一定要去 } \\
\text { 中國 }\end{array}$ & $\begin{array}{l}\text { Wo ie ting yaw tjoey } \\
\text { tjoeng kwo }\end{array}$ & $\begin{array}{l}\text { saia misti maoe } \\
\text { pegi negeri tjina }\end{array}$ & $\begin{array}{l}\text { 'I definitely want to } \\
\text { go to China.' }\end{array}$ \\
\hline
\end{tabular}

In the second volume of Kuo-Yü Zonder Goeroe, we find a very similar exchange, shaming Indies-born Chinese who cannot speak Mandarin (Shen-Tjia 1940: 9, 15-16). A selection of sentences is given below: 


\begin{tabular}{|c|c|c|c|}
\hline $\begin{array}{l}\text { 您說得那末 } \\
\text { 準確, 真可 } \\
\text { 佩服 }\end{array}$ & $\begin{array}{l}\text { nien shuo tê na mo } \\
\text { tj'oen tj'io, tjên k'ê } \\
\text { p'ei toe }\end{array}$ & $\begin{array}{l}\text { Saia merasa kagoem } \\
\text { sekali jang toean bisa } \\
\text { bitjara begitoe teges }\end{array}$ & $\begin{array}{l}\text { 'You speak so } \\
\text { accurately, it's very } \\
\text { admirable' }\end{array}$ \\
\hline $\begin{array}{l}\text { 不敢當, 聽 } \\
\text { 說荷印的華 } \\
\text { 僑, 除了由 } \\
\text { 祖國來的, } \\
\text { 很少能說中 } \\
\text { 國話, 這是 } \\
\text { 確實嗎 }\end{array}$ & $\begin{array}{l}\text { poe kan tang, t’ing } \\
\text { shuo ho yin ti hua } \\
\text { ch'iao, tj'oe liao yoe } \\
\text { tsoe kuo lai ti, hên } \\
\text { shao nêng shuo tjo- } \\
\text { eng kuo hoa, tjé shih } \\
\text { tj'io shih ma? }\end{array}$ & $\begin{array}{l}\text { Trima kasi. Saia } \\
\text { denger Hua Kiao di } \\
\text { Hindia Blanda, } \\
\text { selainnja totok, } \\
\text { sedikit sekali jang } \\
\text { bisa bitjara Tionghoa. } \\
\text { Apatah ini betoel? }\end{array}$ & $\begin{array}{l}\text { 'You flatter me. I hear } \\
\text { that Overseas Chinese } \\
\text { in the Netherlands } \\
\text { Indies, except those } \\
\text { born in China, are } \\
\text { rarely able to speak } \\
\text { Chinese. Is this true?' }\end{array}$ \\
\hline $\begin{array}{l}\text { 是確實的, } \\
\text { 大概有一半 } \\
\text { 不懂自己的 } \\
\text { 語言, 這實 } \\
\text { 在是慚愧 } \\
\text { 得很 }\end{array}$ & $\begin{array}{l}\text { Shih tj'io shih ti, ta kai } \\
\text { yoe i pan poe toeng } \\
\text { tzŭ tji ti yü yan, tjé } \\
\text { shih tjai shih tj'an } \\
\text { k'oei tê hên. }\end{array}$ & $\begin{array}{l}\text { Ini memang betoel, } \\
\text { kira-kira ada separo } \\
\text { jang tida bisa } \\
\text { bahasanja sendiri. Ini } \\
\text { sebetoelnja berasa } \\
\text { maloe sekali }\end{array}$ & $\begin{array}{l}\text { 'This is true, about } \\
\text { half of them don't } \\
\text { understand their } \\
\text { own language. } \\
\text { This is really very } \\
\text { embarrassing.' }\end{array}$ \\
\hline $\begin{array}{l}\text { 中國人不會 } \\
\text { 說中國話, } \\
\text { 當然是害差 } \\
\text { 的.而且會 } \\
\text { 給外國人看 } \\
\text { 不起 }\end{array}$ & $\begin{array}{l}\text { Tjoeng kuo rĕn poe } \\
\text { hoei shuo tjoeng kuo } \\
\text { hoa, tangran shih hai } \\
\text { sioe ti. Ĕrl tj'ië hoei } \\
\text { kei wai kuo rĕn k’an } \\
\text { poe tj'i }\end{array}$ & $\begin{array}{l}\text { Bangsa Tionghoa tida } \\
\text { bisa bitjara bahasanja } \\
\text { tentoe sekali maloe, } \\
\text { dan lagi dipandang } \\
\text { renda oleh lain } \\
\text { bangsa. }\end{array}$ & $\begin{array}{l}\text { 'Chinese people } \\
\text { who cannot } \\
\text { speak Chinese } \\
\text { are definitely very } \\
\text { embarrassing, and } \\
\text { will also be looked } \\
\text { down on } \\
\text { by foreigners.' }\end{array}$ \\
\hline $\begin{array}{l}\text { 因為有了這 } \\
\text { 種感覺, 所 } \\
\text { 以我家兄弟 } \\
\text { 姐妹都趕快 } \\
\text { 學國語了 }\end{array}$ & $\begin{array}{l}\text { Yin wei yoe liao tjé } \\
\text { tjoen kan tjio, so i wo } \\
\text { tjia hsioeng ti tjie mei } \\
\text { toe kan k'oai hsuën } \\
\text { kuo yu liao. }\end{array}$ & $\begin{array}{l}\text { Oleh karna ada ini } \\
\text { pengrasahan, maka } \\
\text { saia poenja soedara } \\
\text { lelaki dan prampoean } \\
\text { semoea pada boeroe- } \\
\text { boeroe berladjar } \\
\text { kuo-yu. }\end{array}$ & $\begin{array}{l}\text { 'Because of this } \\
\text { feeling, my brothers } \\
\text { and sisters are quickly } \\
\text { learning Mandarin.' }\end{array}$ \\
\hline
\end{tabular}

Whereas the first volume of Kuo-Yü Zonder Goeroe contained very few example sentences of a distinct ideological nature, the second volume insisted at various sections that Indies-born Chinese should learn about China and preferably spend time there. Like the Classified Conversations almost three decades earlier, the book's conversations took place in the cities, trains, and boats of China. 
Both books featured conversations on seasickness and ways to handle it, for example. On the topic of dancing, however, Mrs. The proved more conservative than her predecessors. While the latter treated the topic with the awe of novelty, the following conversation in Kuo-Yü Zonder Goeroe reveals that its author had little positive to say about the encroachment of Western dancing on the Chinese culture (Shen-Tjia 1940: 237):

\begin{tabular}{|c|c|c|c|}
\hline $\begin{array}{l}\text { 我想不到, 現 } \\
\text { 在有這麼多中 } \\
\text { 國人跳舞 }\end{array}$ & $\begin{array}{l}\text { Wo siang poe tao, } \\
\text { hsiën tjai yoe tjé mo } \\
\text { to tjoeng kuo rĕn } \\
\text { t'iao woe. }\end{array}$ & $\begin{array}{l}\text { Saia tida sangka } \\
\text { sekarang banjak orang } \\
\text { Tionghoa bisa dansa }\end{array}$ & $\begin{array}{l}\text { 'I didn't expect there } \\
\text { would be so many } \\
\text { Chinese people these } \\
\text { days who dance' }\end{array}$ \\
\hline $\begin{array}{l}\text { 這就是所謂時 } \\
\text { 髦的中國人, } \\
\text { 難道你反對中 } \\
\text { 國人跳舞嗎 }\end{array}$ & $\begin{array}{l}\text { Tjé tjioe shih so wei } \\
\text { shih mao ti tjoeng } \\
\text { kuo rĕn, nan tao ni } \\
\text { fan toei tjoeng kuo } \\
\text { rĕn t'iao woe ma? }\end{array}$ & $\begin{array}{l}\text { Ini jalah jang dibilang } \\
\text { orang Tionghoa mod- } \\
\text { ern. Masatah kaoe } \\
\text { anti orang Tionghoa } \\
\text { dansa? }\end{array}$ & $\begin{array}{l}\text { 'These are the } \\
\text { so-called modern } \\
\text { Chinese. Are you } \\
\text { against Chinese } \\
\text { people who dance?' }\end{array}$ \\
\hline $\begin{array}{l}\text { 絕對反對. 我們 } \\
\text { 出去再繞個圈 } \\
\text { 子吧 }\end{array}$ & $\begin{array}{l}\text { Tj'uëh toei fan toei. } \\
\text { Wo mĕn tj'oe tj'u tjai } \\
\text { rao kĕ tj'uan tzŭ pa! }\end{array}$ & $\begin{array}{l}\text { Tentoe anti. Mari kita } \\
\text { kloear moeter lagi } \\
\text { sekali }\end{array}$ & $\begin{array}{l}\text { 'I'm absolutely against } \\
\text { it. Let's go out and } \\
\text { walk around some } \\
\text { more.' }\end{array}$ \\
\hline
\end{tabular}

The enduring popularity of Mandarin textbooks in Chinese-Indonesian circles negate Oudendijk's observations made in 1913 that "those who have settled here permanently will probably realize that the Mandarin dialect has little "market value" and that "while the written Chinese language can still be counted among the sciences that are useful for the (Chinese) subjects in the Netherlands Indies society, the spoken North Chinese (Mandarin) dialect cannot be considered for this at all". ${ }^{32}$ At the same time, the fact that few of these

$32[\ldots]$ zullen zij die hier voor goed gevestigd zijn wel inzien dat het Mandarijnsche dialect weinig "marktwaarde" heeft (van der Wal 1963: 258); [...] kan men de geschreven Chineesche taal nog rekenen tot die wetenschappen die voor onze (Chineesche) onderdanen in de Nederlandsch-Indische samenleving nuttig zijn, het gesproken Noord Chineesche (Mandarijnsche) dialect kan daarvoor heelemaal niet in aanmerking gebracht worden (ibid. 263). 
educational books - oft-reprinted and well-advertised as they were - can be found in more than one library testifies to a later disinterest in the material. ${ }^{33}$ This is unfortunate, as Chinese-Indonesian linguistic history can only be fully understood by taking into account all elements in the equation: Malay, Mandarin, Hokkien, Javanese, and even Dutch.

In this chapter, hence, I have tried to demonstrate that several insights of historical and linguistic relevance can be gleaned from the pages of Mandarin educational texts, as is the case with phrasebooks and textbooks more generally. As regards the romanization of Mandarin, we may safely conclude that no available system fully "worked"; rather than a consistently implemented system, what arose was a fluid set of conventions. Testimony to this fluidity is the fact that some authors adopted a different romanization over time, while others openly solicited their readers' preferences in this arena. I have focused more on lexicon and textual contents than grammar, which is comparatively difficult to connect with broader social developments, yet the material will undoubtedly also be relevant to scholars interested in the syntactical development of Mandarin.

The latest primary source examined for this chapter dates from 1945 . Mandarin-related materials from the 1950s presumably reveal quite different dynamics. Amidst the triumph of the Indonesian nation-state, books promoting loyalty to another country became politically sensitive. Nevertheless, both the PRC and the ROC - the latter now operating from Taiwan - continued to assert their influence on Chinese-Indonesians in subtle, officially approved ways (Suryadinata 1972; Sai 2006; Zhou 2019). This came with linguistic implications too. In 1955, the PRC adopted a standardization closer to the colloquial language of Beijing - known as Common Speech or Pǔtōnghuà 普通話 - while Taiwan retained the pre-existing standardization that, though also based on the Beijing dialect, preserved a layer of Nanjing lexical influence associated with intellectual speech (Li 2004: 103; Simmons 2017: 65-66). The enforcement in the PRC of simplified characters and of the Pinyin 拼音 romanization, too, took an upward turn from the 1950s. It stands to reason to assume that proBeijing and pro-Taiwan schools taught a slightly different form of Mandarin in 1950s Indonesia, until the latter were banned in 1958 (cf. Suryadinata 1972: 67-70). In precisely these years, calls to outlaw Chinese education and Chinese newspapers rang increasingly louder (cf. Elson 2008: 176-77). Just when only

33 This is especially the case for textbooks written in Malay. The situation for textbooks in Chinese, a collection of which is kept at the Wang Gungwu Library in Singapore, is considerably more favourable. 
one type of Mandarin was left for Chinese-Indonesians to choose from, their very identity had become illicit.

The Mandarin currently taught in Indonesia is chiefly Pǔtōnghuà, in simplified characters. It is avidly studied by Chinese-descended as well as "indigenous" Indonesians. In addition, numerous Indonesian migrant workers have gained fluency - but rarely literacy - in Taiwanese Mandarin. This variety is also taught in a small number of schools. While knowledge of Mandarin is clearly on the rise in Indonesia and elsewhere in Southeast Asia, proficiency in Hokkien, Hakka, Cantonese and Teochew is declining. Indeed, the ongoing Chinese Revival leaves little room for Sinitic varieties other than Mandarin (Sai 2010; Setijadi 2015; Stenberg 2015). As I have demonstrated, this project of homogenization was kick-started a century earlier. Whether it will lead to new episodes of shaming Chinese-Indonesians deemed not fluent enough remains an open question. If anything, doing so would undermine a fascinating history of plurilingualism and fluctuating proficiencies, in which linguistic practices were deeply intertwined with the political pressures of the day.

\section{Acknowledgements}

I am grateful to Azmi Abubakar for his generous help in finding some of the sources for this chapter, and to Josh Stenberg and Caroline Chia for their valuable comments on an earlier draft.

\section{References}

China Weekly Review, Who's Who in China: Biographies of Chinese Leaders (Shanghai: China Weekly Review, 1936).

Chu, K.S., Kim S.L. and Lim B.S., The Chinese, English and Malay Classified Conversations (Batavia: Chun Lim \&Co, 1912).

Chun Foo Chun, Homaro: Hatoeran Oentoek Memake aken Roepa-Roepa Obat atawa Penoendjoek Roepa-Roepa Penjakit dan Obatnja (Batavia: Chun Lim \&Co, 1915).

Chun Foo Chun, S.A.N.O.P.H.I.: Segala apa njang Orang Prampoean Haroes Ingat (Batavia: Lim Bok Sioe, 1917).

Chun Foo Chun, Hoa Woe Ho Pie (Batavia: Chun Lim \&Co, 1920).

Chun Foo Chun, Sin Woe Hoa Tze Tian: Woordenboek Melajoe en Tiong-hoa (Batavia: Chun Lim \&Co, 1930).

Elson, R.E., The Idea of Indonesia: A History (Cambridge: Cambridge University Press, 2008). 
Goh, Yeng-Song, Teaching Chinese as an International Language: A Singapore Perspective

(Cambridge: Cambridge University Press, 2017).

Hau Lai Ying 侯勵英, ‘新學制下的兒童教科書: 民初《國語教科書》 的知識傳播, in Lee Fan (李帆), Hon Tze-ki (韓子奇) and Au Chi Kin (區志堅) (eds.), 知識與認同: 現代學者論教育及教科書 (Hong Kong: Chung Hwa Book Company, 2017): 225-53.

Heryanto, Ariel, 'Ethnic Identities and Erasure: Chinese Indonesians in Public Culture', in Joel S. Kahn (ed.), Southeast Asian Identities: Culture and the Politics of Representation in Indonesia, Malaysia Singapore, and Thailand (London and New York: I.B. Tauris, 1998): 95-114.

Hoogervorst, Tom G., 2021. Language Ungoverned: Indonesia's Chinese Print Entrepreneurs, 1911-1949. Ithaca, NY: Cornell University Press, 2021.

Iskan, Dahlan, 'Wajah Baru Koran Si Oom', Tempo 12/18 (1982): 28.

Knoetsen, John F., Tan Giem Hok and M.B. Sastro Widjojo, Java-Tourists: How to Speak Malay, Javanese and Sundanese (Batavia: Tjiong Koen Bie, 1911).

Knoetsen, John F., East Asia (2nd edn., Batavia: Tjiong Koen Bie, 1912 [1910]).

Knoetsen, John F., Handleiding om Chineesche Karakters te leeren schrijven en lezen (Batavia: De "Pertoendjoengan", 1931).

Knoetsen, John F., Japansche taal voor Hollandsch en Maleisch sprekende toeristen, Hollandsch-Japansch-Maleisch-Engelsch (Batavia: De "Pertoendjoengan”, 1934).

Knoetsen, John F., De Procureur (Batavia: De "Pertoendjoengan”, 1935).

Kuiper, Koos, The Early Dutch Sinologists (1854-1900): Training in Holland and China, Functions in the Netherlands Indies (Leiden: Brill, 2017).

Kwartanada, Didi, 'Mandarin Comes to the South Seas: The Making of Chinese Education in Early Twentieth Century Java', Asian Culture 42 (2018): 37-54.

$\mathrm{Li}$, Chris Wen-Chao, 'Conflicting notions of language purity: The interplay of archaising, ethnographic, reformist, elitist and xenophobic purism in the perception of Standard Chinese', Language \& Communication, 24 (2004): 97-133.

Li Joek Koey, A Classified Dictionary of Chinese-Malay-Dutch-English with Chinese pronunciation (Batavia: Kuo Min Book Co., 1931).

Mahdi, Waruno, 'Linguistic variety in later nineteenth-century Dutch-edited Malay publications', Nusa, 6o (2016): 107-85.

Moerman, J., In en om de Chineesche Kamp (Batavia: G. Kolff, 1929).

Morgan, Evan, Chinese new terms: Revised and enlarged. With English translations, classifications, introduction and index (Shanghai: Kelly \& Walsh, 1932).

Ng, Kim Chew, 'Sinophone/Chinese: "The South where Language is lost" and Reinvented, translated by Brian Bernards', in Shu-mei Shih, Chien-hsin Tsai and Brian Bernards (eds.) Sinophone Studies: A Critical Reader (New York: Columbia University Press, 2013): 74-92. 
Nio Joe Lan, 'De omgangstaal der Chineezen in Indonesië', De Indische Gids, 54/2 (1932): 1089-94.

Nio Joe Lan, 'Iets over Chineesche namen en over het Chineesch in Indonesië', De Indische Gids, 55/1 (1933): 410-18.

Oetomo, Dédé, 'The Chinese of Indonesia and the Development of the Indonesian Language', Indonesia (1991, special issue): 53-66.

Oey Tjiang Hoay, Kitab Logat Baroe Tionghoa-Melajoe (Shanghai: Modern Languages Association, 1935).

Sai Siew-Min, Representing the Past of Chinese Language Education: Language, History and Chinese Identities in Indonesia ( $\mathrm{PhD}$ thesis, University of Michigan, 2006).

Sai Siew-Min, 'Pugilists from the Mountains: History, Memory, and the Making of the Chinese-Educated Generation in Post-1998 Indonesia', Indonesia, 89 (2010): 149-78.

Sai Siew-Min, 'Mandarin lessons: Modernity, colonialism and Chinese cultural nationalism in the Dutch East Indies, c.19oos', Inter-Asia Cultural Studies 17/3 (2016): 375-94.

Setijadi, Charlotte, 'Being Chinese Again:Learning Mandarin in Post-Suharto Indonesia', in Li Wei (ed.), Multilingualism in the Chinese Diaspora Worldwide: Transnational Connections and Local Social Realities (London: Routledge, 2015): 141-57.

Shen-Tjia, Ms. The Chung, Kuo-Yü Zonder Goeroe (Surabaya: New China, 1934).

Shen-Tjia, Ms. The Chung, Kuo-Yü Zonder Goeroe: Djilid Doea (Surabaya: New China, 1940).

Shen-Tjia, Ms. The Chung, Boekoe Beladjar Alphabet Kuo-Yin (Surabaya: New China, 1942).

Simmons, Richard Vanness, 'Whence Came Mandarin? Qīng Guānhuà, the Běijīng Dialect, and the National Language Standard in Early Republican China',Journal of the American Oriental Society 137/1 (2017): 63-88.

South Coblin, W., 'A Diachronic Study Of Míng Guānhuà Phonology', Monumenta Serica 48/1 (2000): 267-335.

South Coblin, W., Modern Chinese phonology: From Guānhuà to Mandarin (Paris: EHESS, 2007).

Suryadinata, Leo, 'Indonesian Chinese Education: Past and Present', Indonesia 14 (1972): 49-71.

Tip Top Toe, Gadis jang dibawa lari (Batavia: Sin Po, 1923).

Tshen, Eric H., Oey Tjiang Hoay and Lim Bok Sioe, Han Woe Tzi Tian: Kitab Lograt Tiong Hoa-Melajoe (Batavia: Kho Tjeng Bie, 1915).

van der Wal, S.L., Het Onderwijsbeleid in Nederlands-Indië 1900-1940:Een Bronnenpublikatie (Groningen: J.B. Wolters, 1963).

Wang, Anyi, 'The Fate of Language (Parts 1 and 2)', Xingzhou ribao, xingyun ban [Sin Chew daily starcloud supplement] (13July and 7 December 1993). 
Wangkar, Max, 'Suratkabar Jawa Pos adalah Dahlan Iskan: Bagaimana dalam 20 tahun satu koran kecil jadi dominan di Indonesia', Pantau 2/13 (2001): 12-25.

Weng, Jeffrey, 'What Is Mandarin? The Social Project of Language Standardization in Early Republican China', The Journal of Asian Studies 77/3 (2018): 611-33.

Yoe Wan Fei, Lim's Boekoe Peladjaran Kuo-Yü Zonder Goeroe (Jakarta: Lim's Boekhandel, 1945).

Zhou Taomo, Migration in the Time of Revolution: China, Indonesia, and the Cold War (Ithaca: Cornell University Press, 2019). 